\title{
Meso- and microscale sea-ice motion in the East Siberian Sea as determined from ERS-1 SAR data
}

\author{
Kim Morris, Shusun Li, Martin JefFries \\ Geophysical Instilute, Lniversity of Alaska Fairbanks, Fairbanks, Alaska 99775-7320, U.S.A.
}

\begin{abstract}
Synthetic aperture radar- $(\mathrm{S} A \mathrm{R}$-) derived ice-motion vectors and $\mathrm{SAR}$ interferometry were used to study the sea-ice conditions in the region between the coast and $75^{\circ} \mathrm{N}(\sim 560 \mathrm{~km})$ in the East Siberian Sea in the vicinity of the Kolyma River. ERS-1 SAR data were acquired between 24 December 1993 and 30 March 1994 during the 3 day repeat Ice Phase of the satellite. The time scries of the ice-motion vector fields revealed rapid (3 day) changes in the direction and displacement of the pack ice. Longer-term ( $\geq 1$ month) trends also emerged which were related to changes in large-scale atmospheric circulation. On the basis of this time series, three sea-ice zones were identificd: the nearshore, stationary-ice zone; a transitional-ice zone; and the pack-ice zone. Thrce 3 day interval and one 9 day intcrval interferometric sets (amplitude, correlation and phase diagrams) were gencrated for the end of December, the begining of February and mid-March. They revealed that the stationary-ice zone adjacent to the coast is in constant motion, primarily by lateral displacement, bending, tilting and rotation induced by atmospheric/oceanic forcing. The interferogram patterns change through time as the sea ice becomes thicker and a network of cracks becomes established in the ice cover. It was found that the major features in the interferograms were spatially corrclated with sea-ice deformation features (cracks and ridges) and major discontinuities in ice thickness.
\end{abstract}

\section{INTRODUGTION}

The continental shelves of the Arctic Ocean arc important for a number of reasons. Much of the ice within the central Arctic ice pack initially formed over these shelves (Pfirman and others, 1995). This sea ice often contains large amounts of fine-grain particulate material incorporated into the ice by suspension freezing (Pfirman and others, 1995), a mechanism which may also be responsible for the incorporation of pollution into the sea-ice cover (Wecks, 1994). Coastal polynyas, which form over the continental shelves, are sites of rapid, copious ice formation which result in considerable heat exchange between the ocean and the atmosphere, and the production of cold, saline water which makes a significant contribution to the cold halocline of the Arctic Ocean (Cavalieri and Martin, 1994).

The most studied Arctic Ocean continental-shelf zone is the Beaufort Sca (c.g. Barnes and others, 1984). By contrast, reconnaissance observations of the Siberian continental-shelf ice regime by Western scientists have only recently been made, and they indicate strong contrasts between this region and the Beaufort Sea that result in large disparities in composition of the sca-ice cover (Gineris and Fettcrer, 1994) and in iccproduction and export rates (Reimnitz and Dethleff, 1994).

The winter sea-ice regime of the $<80 \mathrm{~km}$ wide Alaskan Beaufort Sea shelf is characterized by compression and shearing, which results in the formation of major grounded pressure-ridge systems that stabilize the fast ice on the midshelf with essentially no open-water areas. The Sibcrian shelves are much wider $(>500 \mathrm{~km}$ for the Laptev and East Siberian Seas), and during winter the Siberian Arctic coast is characterized by strong prevailing offshore winds (Riska and Salmcla, 1994) which create a dilational sea-ice cover (Reimnitz and Dethleff, 1994). Therefore, the Siberian shelves may play a much greater role in the dynamics of the Arctic basin vis-à-vis sea-ice production, sediment and pollution entrainment and transportation, and cold, saline water production than their North American counterparts. Most of the recent work in the Siberian Arctic has been in the Barents, Kara and Laptev Seas (e.g. Kassens and others, 1994).

In this study, we focus on the Fast Siberian Sea, the least studied of the Siberian continental-shelf seas. It lies between the New Siberian Islands $\left(145^{\circ} \mathrm{E}\right)$ and Wrangel Island $\left(180^{\circ} \mathrm{E}\right)$. It is the shallowest Arctic sea, with a mean depth of $54 \mathrm{~m}$ (Timokhov, 1994). The Indigirka and Kolyma submarine valleys are the only major features found on its continental shelf (Johnson and others, 1990). Tidal variation here is usually small $(<0.5 \mathrm{~m})$, and the currents are generally from northwest to southeast south of $75^{\circ} \mathrm{N}$, with velocities rarely exceeding $0.25 \mathrm{~m} \mathrm{~s}^{1}$ (Riska and Salmela, 1994). The shallow bathymetry and weak currents favour the formation of fast ice that extends $250-550 \mathrm{~km}$ from the mainland coast (Drent, 1993). . ir temperatures indicate that this ice attains average thicknesses up to $1.72 .0 \mathrm{~m}$ in normal winters (Barnett, 1991). There is no well-developed shear zone in the East Siberian Sea (Riska and Salmela, 1994), and ridge formation here is most likely through ice compression or local ice motion. Ridge heights range from $0.75-1.00 \mathrm{~m}$ in the western East Siberian Sca to $1.75-2.00 \mathrm{~m}$ in the east (Romanov, 1991: map cited in Riska and Salmela, 1994).

In order to study the meso- and microscale sea-ice motion and interactions between the nearshore and offshore ice in the East Siberian Sea, we used ERS-1 synthetic aperture radar (SAR) data to derive ice-motion vector ficlds and 
interferometric information. SAR-derived icc-motion ficlds and interferometry have not previously been used together. SAR-derived ice-motion fields have been used to map seaice movement and deformation in the Arctic Occan (c.g. Kwok and others, 1990; Stern and others, 1995). SAR interferometry has becn used to investigate landfast ice motion during a 1 month period in a small area near Prudhoe Bay, Alaska (Li and others, 1996a). Hcre, we combine the two techniques to investigate ice motion during a 3 month period (December 1993-March 1994) in the East Siberian Sea along a $100 \mathrm{~km}$ wide swath extending from the coast, at the mouth of the Kolyma River, to $75^{\circ} \mathrm{N}$, approximately $560 \mathrm{~km}$ offshore (Figs 1 and 2).

\section{DATA AND METHODS}

The first Earth Resources Satellite (ERS-1) was launched by the European Space Agency (ESA) in July 1991. It acquired SAR signals at C-band ( $56.6 \mathrm{~mm}$ wavelength) in $100 \mathrm{~km}$ wide swaths. The resulting SAR imagcs can be cither amplitude (or amplitude-of-backscatter) images or complex images which contain both amplitude and phase information from the synthesized radar returns. The reader is referred to the Alaska SAR Facility website [http://www.as [alaska.edu] for instrument and product specifications.

ERS-1 was placed into an Ice Phase from 23 December 1993 to 10 April 1994, during which time the satcllitc passed over the same geographical position at the same time of day every 3 days (Fig. 1). At this time of year, air temperatures are well below freezing in the study area; therefore, backscatter variability due to temperature fluctuations (i.e. rapid freezing or melting within the snowpack is minimal. This high volume of temporally closely spaced data allowed us to generate two different kinds of sea-ice-motion products. For

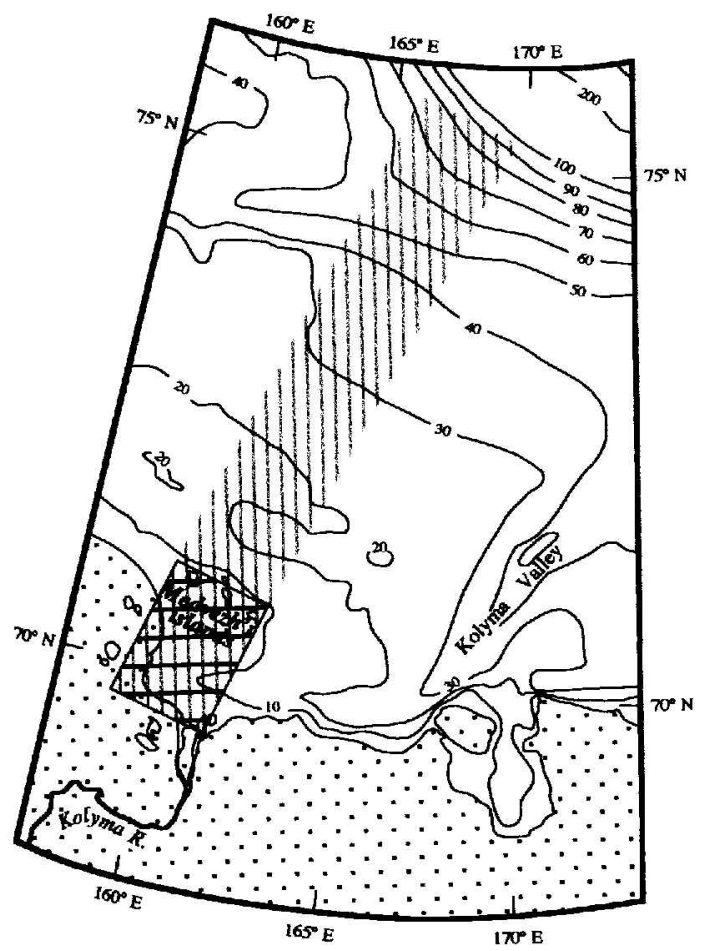

Fig. 1. Map of the study area showing the bathymetry, the footprint of the ERS-1 3 day repeat orbits (light-gray cross-hatched box) between 24 December 1993 and 30 March 1994 and the general location of the interferograms south of the Medvezh islands (small, dark box). The isobaths are in meters.

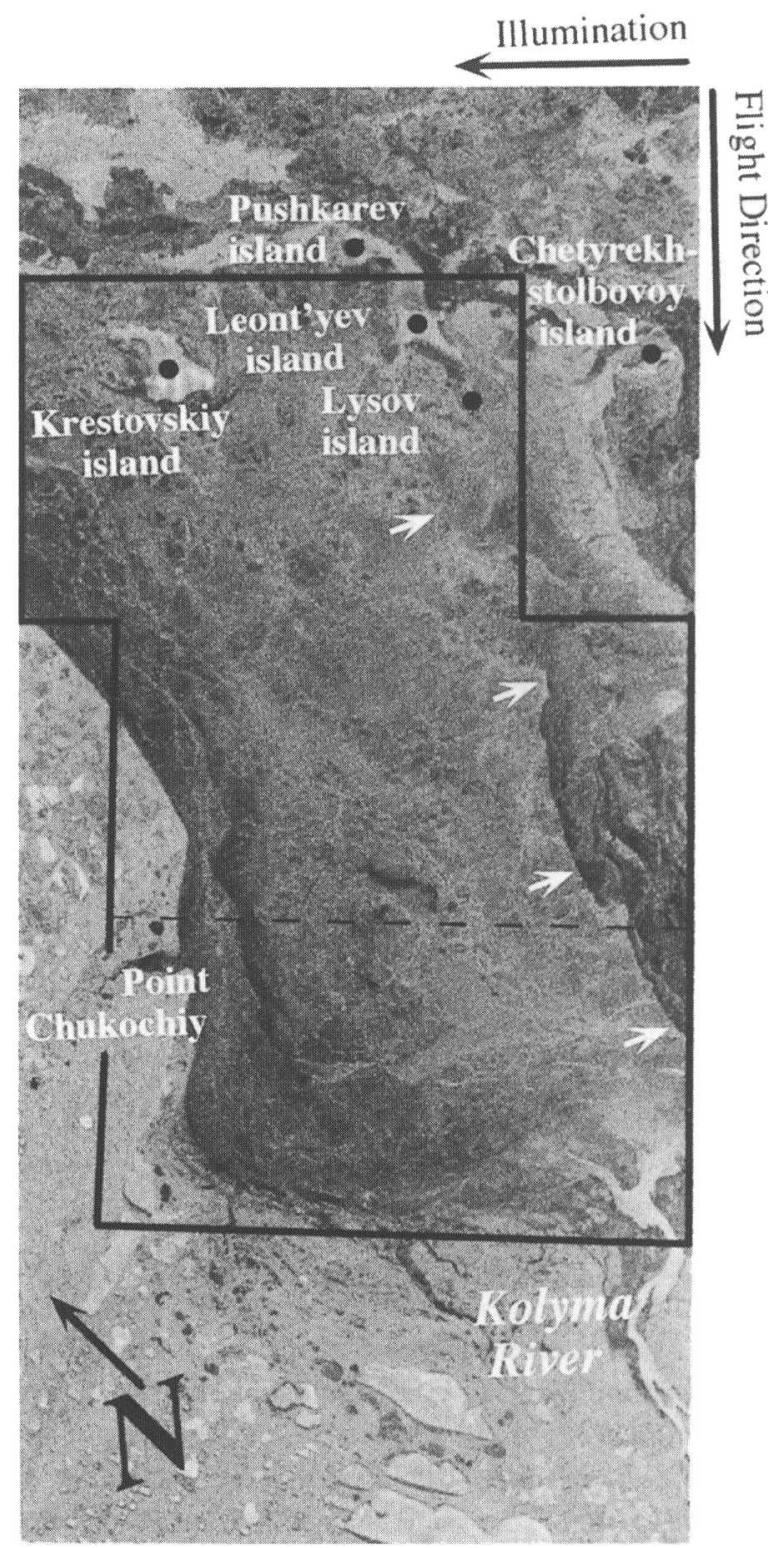

Fig. 2. The general locations of the interferogram mosaics are superimposed on calibrated standard low-resolution ERS-I SAR images acquired 30 December 1993. The dolled line in the lower box is the southern extent of the $S A R$ data acquired on 27 December 1993 and between 4 and 13 February 1994. The SAR mosaic illustrates the sea-ice radar backscatter pattern south of the Medvezh islands which persisted from $5 \mathrm{D} \ell-$ cember 1993 to the onset of melt in May 1994. The sharp ice boundary that extends from Leont'yev island to the Kolyma River delta (indicated by the white arrores) is a result of differences in the age of the sea ice on either side. The satellite flight direction and $S A R$ illumination (look) direction for all of the SAR data used in this study are the same as those indicated here. The swath is approximately $100 \mathrm{~km}$ wide and $320 \mathrm{~km}$ long.

mesoscale sea-ice movement, explicit icc-motion vector fields (displacement not velocity) were generated. For very smallor microscale sea-ice-motion ice south of the Mcdvczh'i islands, interferograms were generated.

\subsection{Ice-motion vectors}

The ice-motion vector fields were generated from low-resolution ERS-1 SAR images by using a modified version of the Alaska SAR Facility Geophysical Processor System (ASF- 
GPS). 'The area over which the ice-motion vectors were generated for this study is shown in Figure 1. This swath of desccnding SAR images extends from $75^{\circ} \mathrm{N}$ to the shoreline of the East Siberian Sea in the vicinity of the Kolyma River (Fig. 2). Once the vector fields were generated, erroncous displacement vectors (flyers), i.e. those that were in clear disagreement with surrounding vectors, were identified visually and removed manually. The datasets were then combined (mosaicked) to create a continuous vector field from the coast to $75^{\circ} \mathrm{N}$. In the plottcd data, any motion $<500 \mathrm{~m}$ is depicted as an arrowhead with no tail: these usually occur south of the Medvezh islands.

A full description of the ASF-GPS specifications and performance, including the gencration of erroneous vectors, can be found in Kwok and others (1990), Kwok and Cunningham (1993), Li and others (1995) and Stern and others (1995). Accuracy of vectors is at least $300 \mathrm{~m}$ and is approximately $100 \mathrm{~m}$ in areas of relatively little deformation. In a recent study by Overland and others (1998), ice-motion vectors generated by the ASF-GPS were compared with ice-motion fields derived from 11 global positioning system buoys in a $20 \mathrm{~km}$ array centered on the SIMI (Sea Ice Mechanics Initiative) Ice Camp: the authors report good correspondence between the deformation of the buoy array and that from the SARgenerated ice-motion vectors.

A total of 286 ERS-1 low-resolution images, acquired betwcen 0049 and $0052 \mathrm{~h}$, were used to produce 323 day repcat ice-motion vector fields starting 24-27 December 1993 and ending 27-30 March 1994.

\subsection{Interferometry}

The details of satellite radar interferometry using SAR data are well documented ( $\mathrm{Li}$ and Goldstein, 1990; Zcbker and Villansenor, 1992; Madsen and others, 1993; Massonnet and Feigl, 1995; Li and others, 1996a), and it has been shown that it is possible to detcet very small changes in elevation $(\leq 10 \mathrm{~mm}$ ) over large areas $(50 \mathrm{~km})$ using this technique (Gabriel and others, 1989). Interferometry has becn used extensively to investigate the effects of earthquakes (Massonnet and others,
1993, 1994; Peltzer and others, 1994; Zebker and others, 1994; Peltzer and Roscn, 1995) and to study the movement of glaciers and ice shcets (Goldstein and others, 1993; Joughin and others, 1995; Rignot and others, 1995, 1997). However, the application of interferometric techniques to sea icc has been limited and the results more difficult to interpret due to the highly variablc rates, magnitudes and direction of displacement ( $\mathrm{Li}$ and others, 1996a).

A detailed discussion and a schematic of the procedure used in this study can be found in Li and others (1996a). This procedure creates three products: an amplitude diagram, a correlation diagram and a phase diagram or interferogram (Fig. 3). The amplitude diagram is the pixel-by-pixel geometric average of the amplitudes of the two source-complex images which is averaged over a $60 \mathrm{~m}$ by $40 \mathrm{~m}$ window. It represents the backscatter values as seen in a standard ERS-I SAR image. The correlation diagram is a map of the degree of phase signal agreement between the two source images which are divided into nine ( 3 by 3 ) overlapping image blocks. Corrclation values are mapped with the lighter areas indicating high corrclation, and the darker areas low correlation: values $<0.3$ are regarded as noise in the signal and mapped as decorrelated. When there is almost total correlation between the two complex images, the correlation diagram clcarly shows very small, poorly correlated features unseen in the amplitude diagram (Fig. 3) but which represent a detectable physical change in the ice.

The phase diagram indicates the change in phase between the two source images in the beam direction, i.e. the component of the displacement which points toward the satcllite (Massonnet and others, 1993). Each fringe is equivalcnt to a change in slant range which is half the length of the radar wavelength (i.e. $28 \mathrm{~mm}$ ). Factors contributing to the change in phase include: the orbital-scparation and beam-path geometry; effects of topography including curvature of the earth; small lateral translations of features; and changes in the slope of the surface (tilt) or rotation of the objects between image acquisitions. Small-scale changes in the sea-ice surface configuration, which in turn cause changes in the phase pattern, are induced by atmospheric
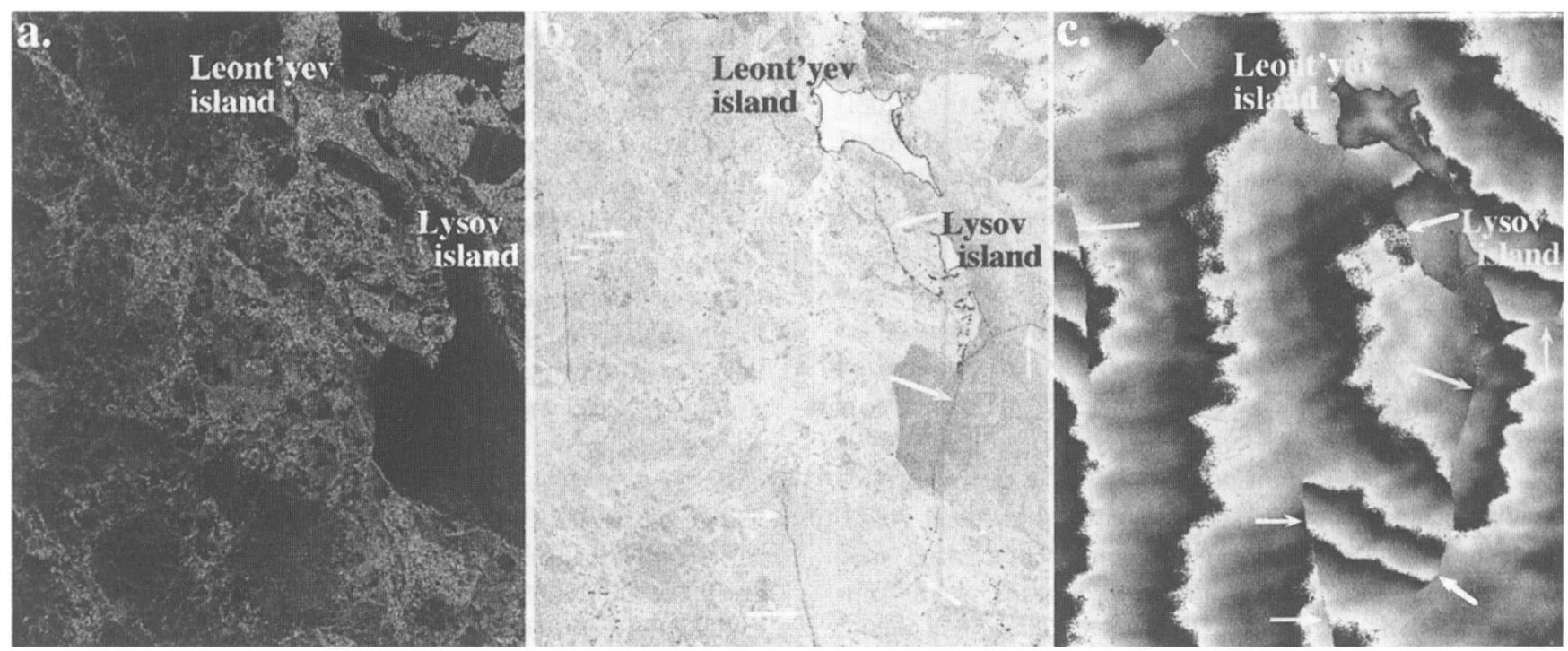

Fig. 3. Fxamples of the three products generaled from complex images using Li and others' (1996 a) procedure. Representing the period 1518 March 1994, the products are: (a) the amplitude diagram; (b) the correlation diagram; and (c) the phase diagram (interferogram). In (a), note the brighter, highly deformed sea ice and the boundary betreen this ice and the younger, darker ice. The arrowes in $(b)$ highlight dark linear zones which represent areas of low correlation, in this case fractures that formed in the sea ice between 15 and 18 March. These are manifested as phase discontinuities in (c). 
and oceanic forcing (including tides) and the redistribution of the snow cover on the ice ( $\mathrm{Li}$ and others, $1996 \mathrm{~b}$ ).

The interferometric algorithm used in this study makes corrections for the nature of the SAR systcm, differences in the orbital gcometry (bascline) of the sequential passcs and the effects of the curvature of the earth ( $\mathrm{Li}$ and others, 1996a). The spatial extent of the baseline is one of the critical factors in this procedure. The smaller the baseline separation, the lower the sensitivity to topography and any residual topographic errors (Massonnet and others, 1995). In our case, the sea-ice topography (ridges) has an average maximum height of $1.50 \mathrm{~m}$ (Romanov, 1991: map cited in Riska and Salmela, 1994). Our baseline separations are sufficiently small that the effects of the sea-ice topography, i.e. introduction of extraneous fringes, are minimal (Table 1). A $1.5 \mathrm{~m}$ ridge would induce only 0.17 extraneous fringes between a ridge and its surrounding area for the worst casc in the dataset, i.c. the interferogram with the largest bascline separation (24 December 1993 to 02 January 1994). Thus, errors introduced into the interferogram by the seaicc topography arc minimal.

Table 1. Summary of phase diagram.s (interferograms)

\begin{tabular}{ccccc}
\hline Date & Interval & $\begin{array}{c}\text { Number of } \\
\text { phase diagrams }\end{array}$ & $\begin{array}{c}\text { Baseline } \\
\text { separation }\end{array}$ & $\begin{array}{c}\text { Estimated } \\
\text { error (docle) }\end{array}$ \\
dd/mm/yy & days & & m & \\
\hline $24 / 12 / 93$ to $27 / 12 / 93$ & 3 & 4 & -41 & 0.02 \\
$27 / 12 / 93$ to $30 / 2 / 93$ & 3 & 4 & -140 & 0.069 \\
$30 / 12 / 93$ to $02 / 01 / 94$ & 3 & 6 & -157 & 0.077 \\
$24 / 12 / 93$ to $02 / 01 / 94$ & 9 & 6 & -340 & 0.167 \\
$04 / 02 / 94$ to $07 / 02 / 94$ & 3 & 4 & 1 & 0 \\
$07 / 02 / 94$ to $10 / 02 / 91$ & 3 & 4 & 79 & 0.039 \\
$10 / 02 / 94$ to $13 / 02 / 94$ & 3 & 4 & -145 & 0.071 \\
$04 / 02 / 94$ to $13 / 02 / 94$ & 9 & 4 & -225 & 0.11 \\
$15 / 03 / 94$ to $18 / 03 / 94$ & 3 & 6 & -62 & 0.03 \\
$18 / 03 / 94$ to $21 / 03 / 94$ & 3 & 6 & -82 & 0.04 \\
$21 / 03 / 94$ to $24 / 03 / 94$ & 3 & 6 & -9 & 0.004 \\
$15 / 03 / 94$ to $24 / 03 / 94$ & 9 & 6 & -156 & 0.076 \\
\hline
\end{tabular}

* Portion of extranrous fringe introduced intn interfernoram hy a $1.5 \mathrm{~m}$ ridge lor the given baseline separation.

Very noisy interferograms.

The interferograms gencrated for this study are located south of the Medvezh islands where the sea-ice cover is most stable (Fig. 2). A total of 62 complex images were used to produce 60 interferograms spanning 3 day and 9 day intervals (Table 1).

\section{MESOSCALE ICE MOTION}

In the Arctic sea-ice pack, ice motion is largely a response to local winds and ocean currents (including tides), while the ice cover closer to the shore can experience internal stress gradients of similar magnitude to the wind and ocean forcing ('Thorndike and Colony, 1982). On a scale of days to months, and in a location some distance from the coast, geostrophic winds account for $>70 \%$ of the sca-ice-motion variance (Thorndike and Colony, 1982). In the Beaufort Sea, as the winter progresses, ice velocities decrease at the nearshore locations until the ice becomes truly fast, experiencing typical motions of only a few tens of meters over the rest of the winter; offshore, the velocity of the pack decreases during winter to an average of $1-2 \mathrm{~km} \mathrm{~d}^{-1}$, but at times the whole ice pack may be nearly motionless for several days (Weeks and others, 1983).

A comparison of the 323 day interval ice-motion vector fields generated for the Ice Phase to the daily surface-pressurc patterns of the same period (Rigor and Colony, 1995; Rigor and Heiberg, 1995) confirms a high correlation betwecn the dominant wind patterns, i.e. atmospheric pressure patterns, and the direction of ice motion, particularly in the pack-ice zone. The strip mosaics in Figure 4 show examples of the output of the ice-motion vector algorithm for the periods 23-26 and 26-29 January 1994 superimposed on SAR image mosaics from 26 and 29 January 1994, respectively. The relevant sea-surface pressure charts are also shown: they illustrate the atmospheric forcing responsible for the rapid change in ice-motion direction and rate of displacement evident in the SAR strips. Between 23 and 25 January (Fig. $4 c-e$ ), the region is dominated by a high-pressure cell which induces flow to the west which becomes more southwesterly as low pressure moves up from the south and is centered over northwest Alaska. Between 26 and 28 January (Fig. $1 \mathrm{f}-\mathrm{h}$ ), the flow becomes predominantly northeasterly as a low-pressure cell moves from the Barents Sea towards the North Pole. A comparison of Figure $4 \mathrm{a}$ and $\mathrm{b}$ shows that in a matter of a few days, there is a significant increase in the area of ice that has detectable motion ( $>500 \mathrm{~m}$ displacement), which is a result of stronger air flow across the East Siberian Sea.

The 32 ice-motion vector fields are summarized in Figure 5 . In tcrms of direction, 16 of the ice-motion vector fields are predominantly offshore, 8 are onshore, 7 have motion towards either the east or west and 1 has no motion (2l-24 March;. From 24 December 1993 to 22 February 1994, the ice-motion direction is predominantly westerly (northwesterly to southwesterly) with only two exceptions, and the longest period of substantial ice displacement occurs between 30 December 1993 and 17 January 1994 (predominantly northwesterly). From 22 February to $30 \mathrm{March}$, the ice motion is easterly (i.e. north-south through the castern quadrant) with no motion with a marked westerly component. This change in the dominant ice-motion direction can be explained by the monthly average surfacc-prcssure pattcrns. During January 1994 a strong high-pressure cell (>14 mbar difference in pressure between the cell center and the studyarea coastline) is centered near $80^{\circ} \mathrm{N}, 170^{\circ} \mathrm{W}$ over the central Arctic basin, producing a well-developed air flow to the northwest over the East Siberian Sea (e.g. Fig. $4 \mathrm{c}-$ e). During February, a high-pressure cell is centered north of Wrangel Island and is quitc weak $(<4$ mbar difference in pressure between the cell center and the study-area coastline). During March, a high-pressure cell is located over the Sibcrian coast centercd somewhere near $140^{\circ} \mathrm{E}$, producing air flow that is to the east-southeast over the Fast Siberian Sca $\left(>12\right.$ mbar difference in pressure from $70^{\circ}$ to $80^{\circ} \mathrm{N}$; e.g. Fig. 4b). Thus, the dominant ice-motion direction in January is northwesterly, and in March is casterly, with morc variable ice motion in February, as inferred from the relatively weak (and possibly less consistent) average monthly pressure pattern for this month.

The ice-motion vector fields were divided into 1 wo or three different zones based on relative ice displacement. The zone closest to the coast represents the region where ice motion is $<500 \mathrm{~m}$ over each 3 day interval and is 

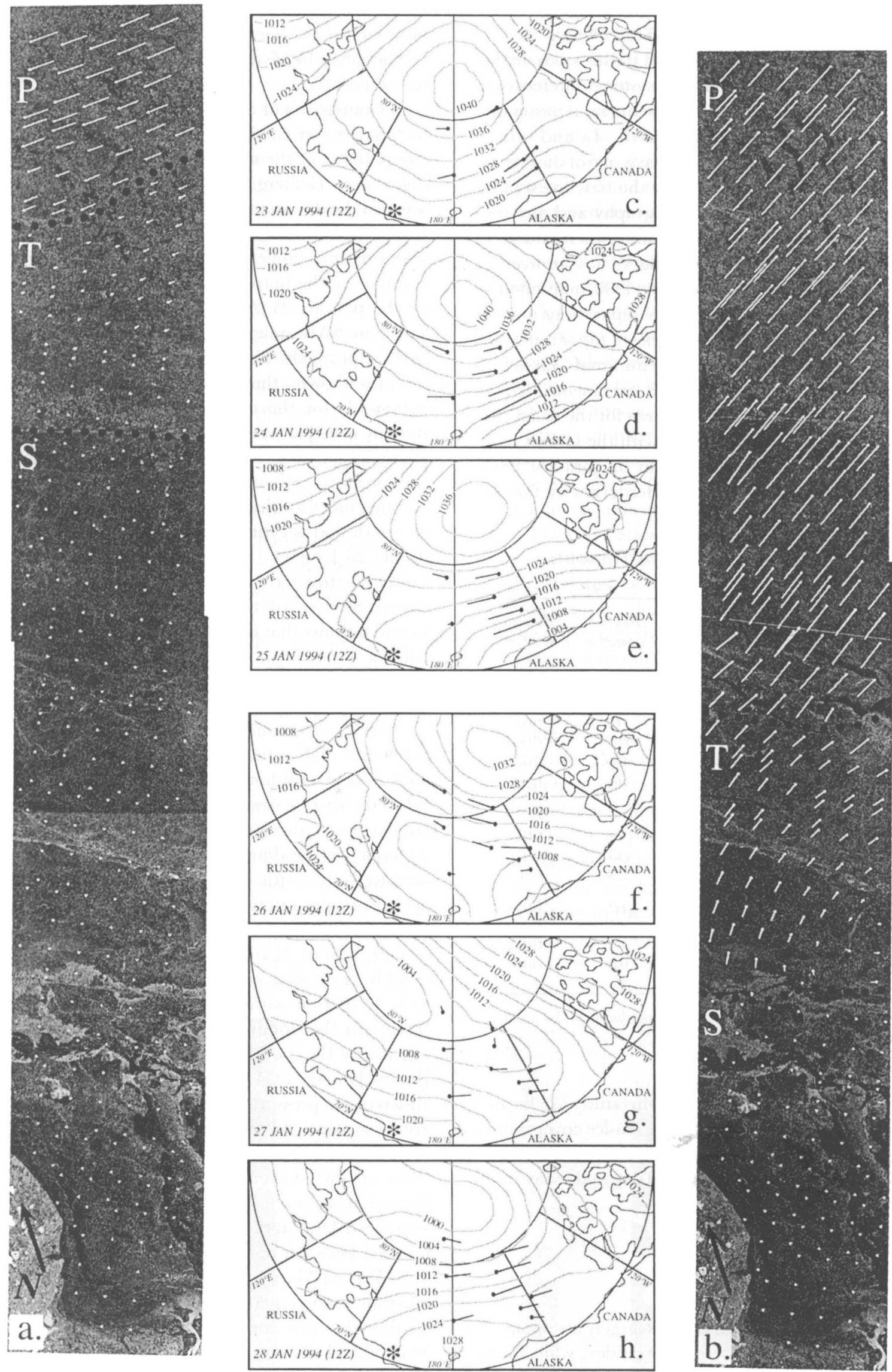

Fig. 4. Two examples of ice-motion (displacement) vector fields fram (a) 23-26 January 1994 and (b) 26-29, January 1994, superimposed on mosaics of uncalibrated, geolocated standard low-resolution ERS-I SAR images acquired on the latter date of each pair. These examples illustrate the variability and rapid change of the sea-ice motion. Each field is dizided into three zones: the stationary-ice zone ( $S$ ); the transitional-ice zone ( T); and the pack-ice zone ( $P$ ). The transitional-and pack-ice zones shift to the south as the nearshore ice undergoes substantial northward lateral motion producing open leads just north of the $T / P$ boundary. The relevant sea-surface pressure charts, derized from IABP data, are shown with isobars in mbar. Buoy motion is depicted by the filled circle (start point) and line (direction and displacement). The East Siberian Sea lies approximately $145-180^{\circ}$ E. The nearshore area adjacent to the Kolyma River is identified by the asterisk. 
referred to as the stationary-ice zone. The vectors in the stationary zone are usually randomly oriented, and south of the Medvezh islands (Figs I and 2) the ice can be considered cssentially landfast. The stationary-ice zonc is in place during 30 of the 32 ice-motion vector-generation intervals and extends from the shore to anywhere between approximately $70.9^{\circ}$ and $74.55^{\circ} \mathrm{N}$. The region furthest to the north represents the icc which is moving at a near-uniform speed and direction during any given 3 day interval and is referred to as the pack-ice zone. Betwcen the stationary-and pack-ice zones, a transition zone may occur: here, the ice-motion vectors are either in a different direction or indicate a different rate of motion than the pack ice. The extent of this transitional-ice zone varies greatly, but in general it lies between $71.5^{\circ}$ and $73.5^{\circ} \mathrm{N}$ (Fig. 5). Its greatest extent was $2.4^{\circ}$ of latitude, and on eight occasions it did not occur at all. From 24 December 1993 to 30 March 1994 the transitional-ice zone never extended north of $74.5^{\circ} \mathrm{N}$. On only two accasions did it extend to the coast: from 30 December 1993 to 2 January 1994 and from 2 to 5 January 1994.

On ten occasions, leads formed at the boundaries between the ice zones (e.g. Fig. 4b); on threc of thesc occasions leads marked both the stationary/transitional ice boundary and the transitional/pack-ice boundary. Most of these leads were active for only 3-6 days, but an extended episode of lead opening and closing occurred in mid-March. From 9 to 12 March, a large lcad system was located at the transitional/pack-ice boundary; from 12 to 21 March, it constituted the northern boundary of the stationary-ice zone.
The stationary/transitional ice boundary was locatcd over this closed lead from 24 to 30 March.

The region south of the Mcdvezh islands can be considered landfast. Landfast ice can move laterally on a very small scalc and it also flexes, rotates, tilts and/or breaks in situ. These subtle ice movements become apparent when interferometric techniques are applied to the SAR data from this area.

\section{MICROSCALE ICE MOTION}

ERS-1 SAR data revealed that by mid-November the sea ice in the nearshore region of the study area was wcll cstablished. $A$ lead was opening up on 16 November (orbit 12214) and 19 November (orbit 12257): it appeared to follow the $10 \mathrm{~m}$ isobath north and west of the Medvezh islands, then proceeded across the Kolyma submarine valley and followed the $10 \mathrm{~m}$ isobath along the shore east of the Kolyma River. By 5 December (orbit 12486), the sea-ice pattern south of the Medvezh islands had become fixcd (Fig. 2). The lead across the Kolyma submarine valley had extended north to Lysov and Leont'yev islands, intersecting the refrozen lead just north of these islands. The resulting sca-ice pattern was seen in all of the SAR images acquired from this date until 21 May 1994.

As mentioned above, small lateral translations of features, changes in the slope of the surface (tilt), and rotation of the objects between image acquisitions produce changes in SAR phase signals. Li and others (1996a) summarized

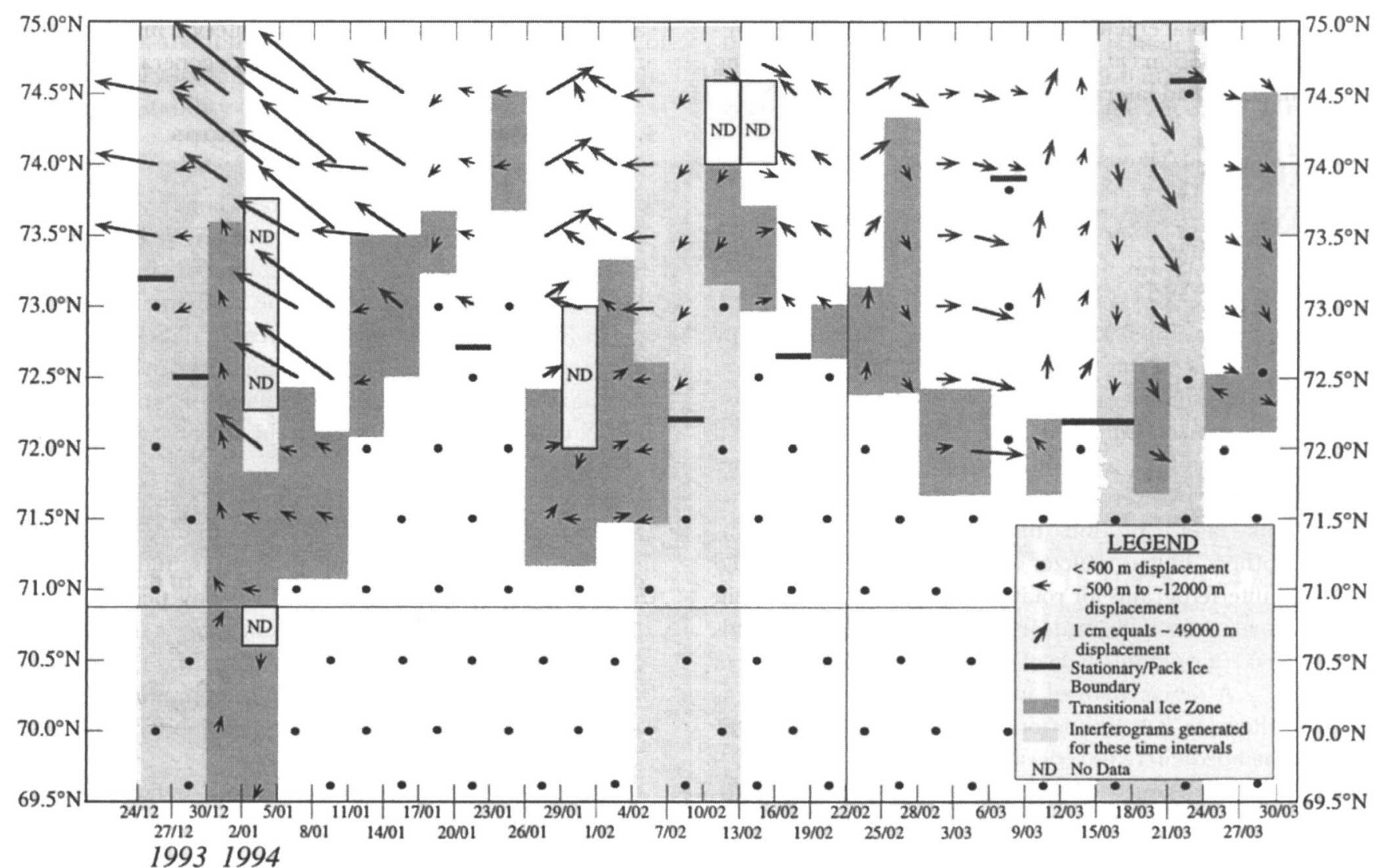

Fig. 5. Summary of the ice-motion (displacement) vector fields generated between 24 December 1993 (24/12) and 30 March 1994 (30,03). The direction of the arrows is true ( north at top of the graph). The length of the gray arrows has a true scale; the length of the black arrows represents a range of displacements which are less than the resolution of the graph. The three lightly shaded columns indicate the time periods for which interferograms were generated for the area south of the Medvezh islands. The dark-shaded areas represent lhe iransitional-ice zone. The horizontal line at $70.9^{\circ}$ N represents the northern extent of the Medvezh islands. The vertical line represents a break between the predominantly westerly ice motion at the beginning of this period and the predominantly easterly ice motion at the end. 


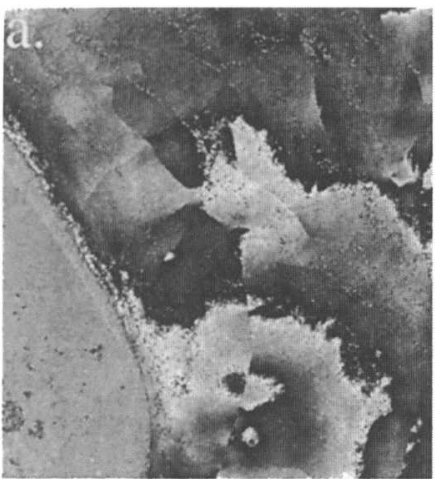

24 December

to 27 December

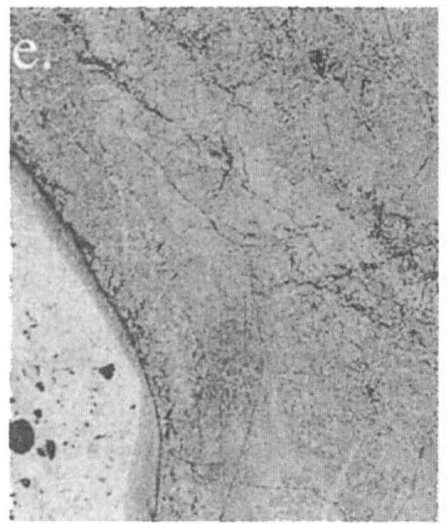

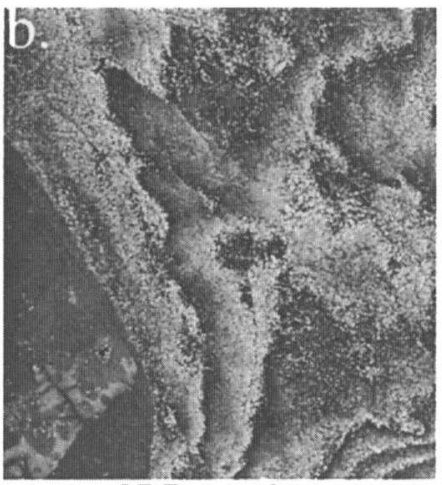

27 December

to 30 December

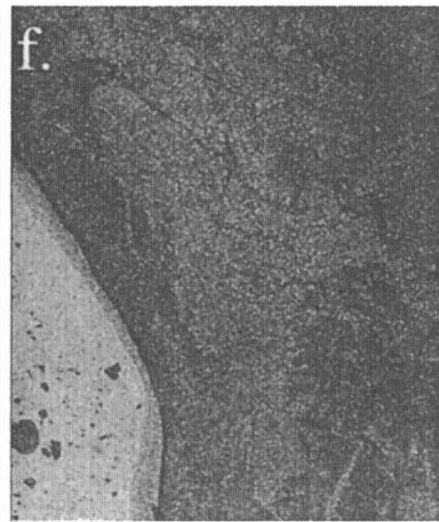

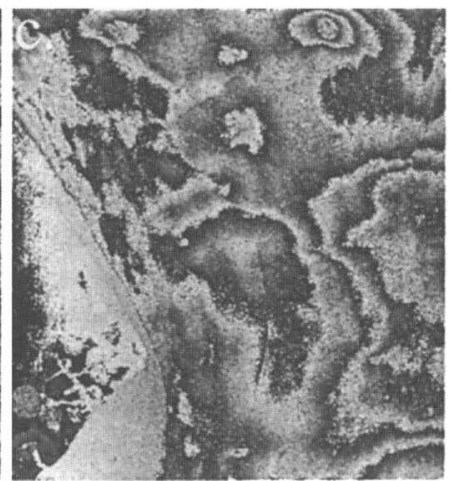

30 December

to 2 January

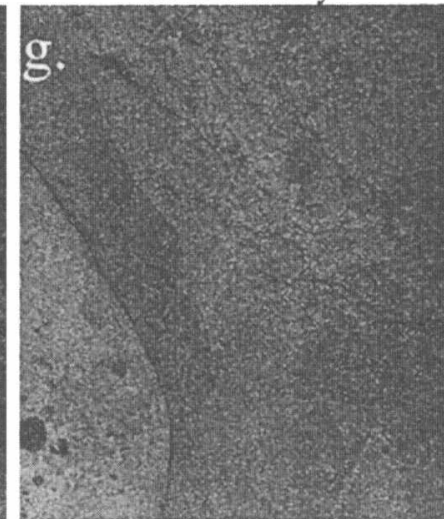

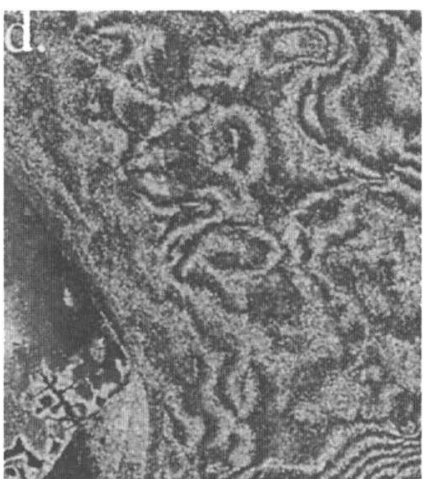

24 December

to 2 January

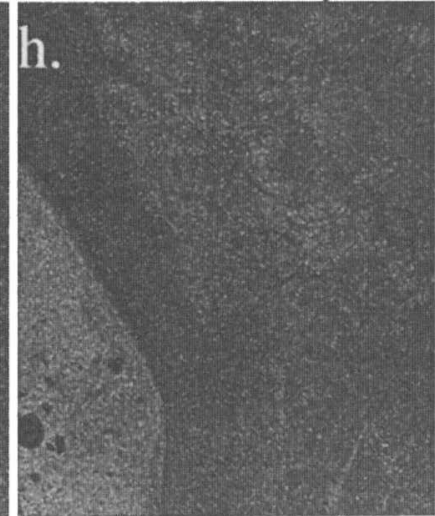

Fig. 6. Sub-scenes from each of the four interferogram (top row) and correlation (bottom row) mosaics conering the time period 24 December 1993 to 2 January 1994. Each sub-scene is approximately $40 \mathrm{~km}$ by $50 \mathrm{~km}$.

the differential interferometric phase $\left(\Delta^{2} P_{c}\right)$ between points (a) and (b) which comprises the terms of bulk and differential displacement components, i.e. tilt $(\Delta w)$, uniform vertical motion $\left(w_{\mathrm{a}}\right)$, differential translation, including rotation, $(\Delta u)$ and lateral displacement $\left(u_{\mathrm{a}}\right)$, as:

$$
\begin{aligned}
\Delta^{2} P_{\mathrm{c}} & =\frac{4 \pi}{\lambda}\left[\Delta w \cos \alpha_{\mathrm{b}}+w_{\mathrm{a}}\left(\cos \alpha_{\mathrm{b}}-\cos \alpha_{\mathrm{a}}\right)\right. \\
& \left.+\Delta u \sin \alpha_{\mathrm{b}}+u_{\mathrm{a}}\left(\sin \alpha_{\mathrm{b}}-\sin \alpha_{\mathrm{a}}\right)\right],
\end{aligned}
$$

where $\lambda$ is the instrument wavelength and $\alpha$ is the incidence angle.

It should be noted that while tilt and rotation in any direction produce fringes, uniform or differential lateral motion in the along-track direction produces no fringes. 'The implication of Equation (l) is that small differential movements (rotation and tilting) introduce many more fringes into the interferogram than do larger, uniform displaccments (lateral motion) in non-along-track directions (Ii and others, 1996a). Peltzer and others (1994) generated synthetic interferograms for rotation and tilt for five different rotation angles which illustrate fringe densitics and thresholds of coherence (a rotation angle of about $0.2^{\circ}$ and a tilt angle of about $0.1^{\circ}$ ). A fringe pattern in a sea-ice interferogram is often produced by a combination of the displacement factors, and can be adequately interpreted only in conjunction with other relevant data such as local sea-ice thickness and topography and concurrent meteorological and oceanographic conditions. Unfortunately, there are no such field data for the study area, so certain inferences will be made from the satellite imagcs and the relevant sea-surface pressure charts derived from the International Arctic Buoy Program (IABP) data (Rigor and Colony, 1995; Rigor and Heiberg, 1995).

Interferograms for the arca within the $10 \mathrm{~m}$ isobath to the south of the Medvezh islands (Fig. 2) were generated for three periods (24 December 1993 to 2 January 1994, 4-13
February 1994 and 15-24 March 1994) which approximate the beginning, middle and end of the ERS-l Ice Phase. For each time period, three sets of 3 day interval interferograms and one set of 9 day interferograms were generated (Table 1 ).

\subsection{Three-day interval interferograms}

The interferograms for the December-January period (Fig. 6) become increasingly complex, and less well correlated, through time, with the last 3 day intcrval interferogram (Fig. 6c) most closely resembling the 9 day interval interferogram (Fig. 6d). This indicatcs increased phase change and thus increased ice movement. During this time period, the stationary-ice zone decreased in extent from approximately $73.2^{\circ} \mathrm{N}$ to the coast $\left(69.5^{\circ} \mathrm{N}\right)$, and the pack-ice displacement was generally oflshore (Fig. 5).

By contrast, the interferograms generated for early to mid-February become less complex and noisy and incrcasingly well correlated as time progresses, indicating that the ice becomes less active over this 9 day period (Fig. 7 ). 'The first 3 day interval interferogram (Fig. 7a) most closely resembles the 9 day intcrferogram (Fig. 7 d). 'The extent of the stationary-ice zone increases from approximately $71.5^{\circ}$ to $73.2^{\circ} \mathrm{N}$, and the pack-ice displacement shifts from east to west to onshore (Fig. 5).

The interferograms generated for mid- to late March are the least variable and best correlated of the three sets (Fig. 8). The sea-ice activity is significantly lower than in the previous periods. Overall, the stationary-ice zone increases in extent from $72.2^{\circ}$ to $74.5^{\circ} \mathrm{N}$, although there is a temporary reduction between 18 and 21 March from $72.2^{\circ}$ to $71.7^{\circ} \mathrm{N}$, and the pack-ice displacement is generally onshore (Fig. 5).

Overall, the complexity and degree of correlation of the intcrferograms appears to have some correlation with the extent of the stationary-ice zonc. The extent of the station- 


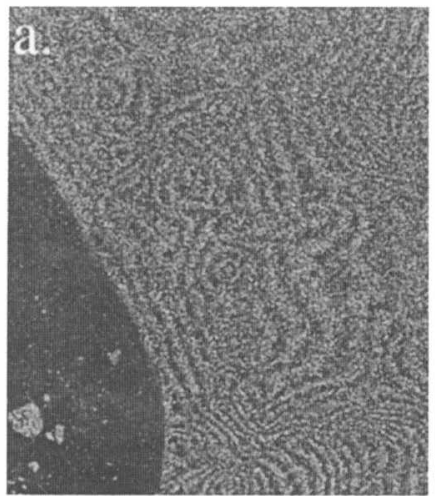

4 February to 7 February

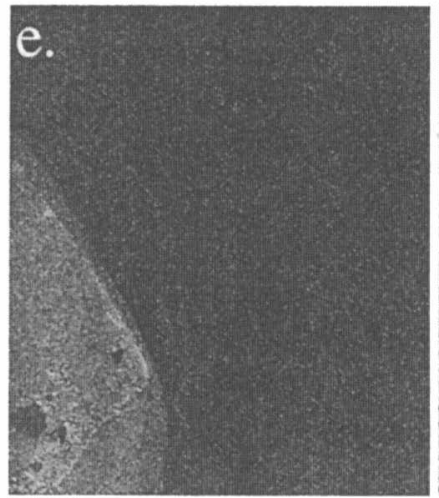

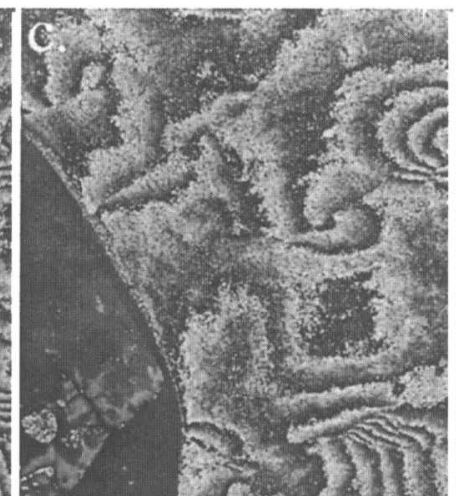

10 February to 13 February

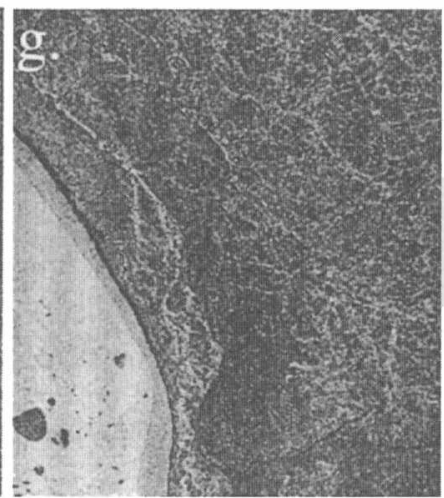



4 February to 13 February

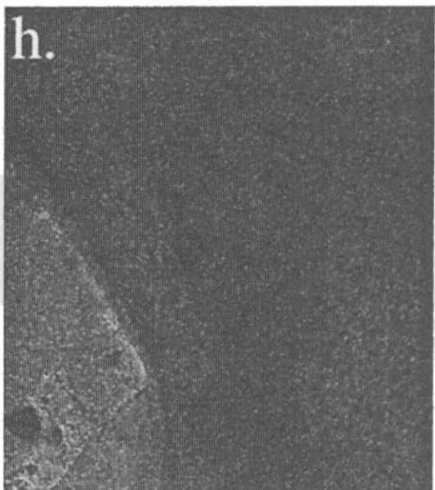

Fig. 7. Sub-scenes from each of the four interferogram (top row) and correlation (bottom row) mosaics covering the time period 4-13 February 1994. Each sub-scene is approximately $40 \mathrm{~km}$ by $50 \mathrm{~km}$.

ary-ice zone is a function of the strength and persistence of the factors which induce ice motion, primarily local winds and currents and internal stresses. The greater the extent of the stationary-ice zone, the weaker these forces are and the greater the stability (i.e. lack of overall motion) of the sea- ice cover. This is particularly evident in the March sequence when a reduction in the extent of the stationary-ice zone between 18 and 21 March (Fig. 5 ) is matched by an overall reduction in the degrec of correlation in the correlation diagram (Fig. 8). Therefore, the stationary-ice zone is respond-

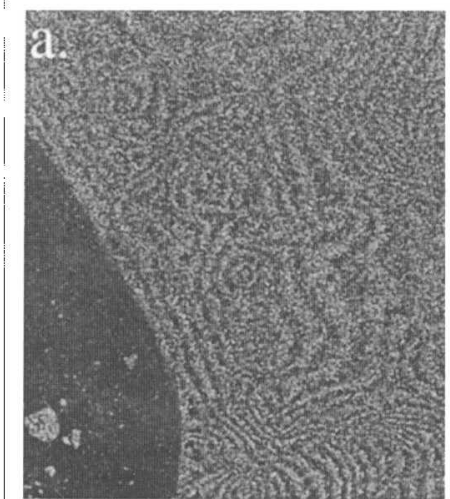

4 February to 7 February

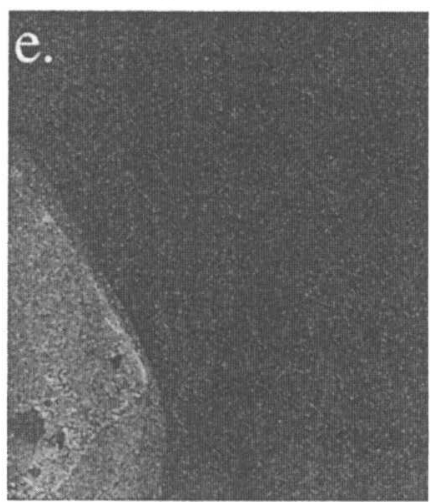

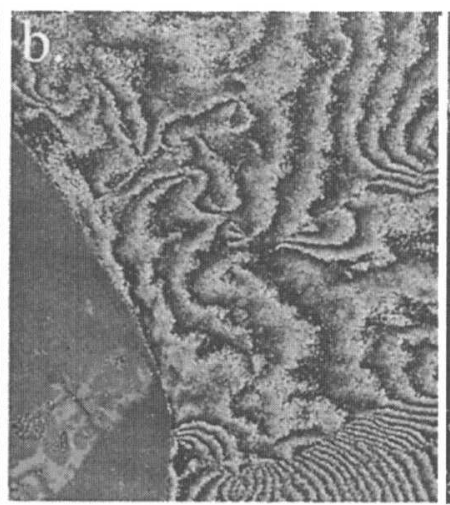

7 February to 10 February

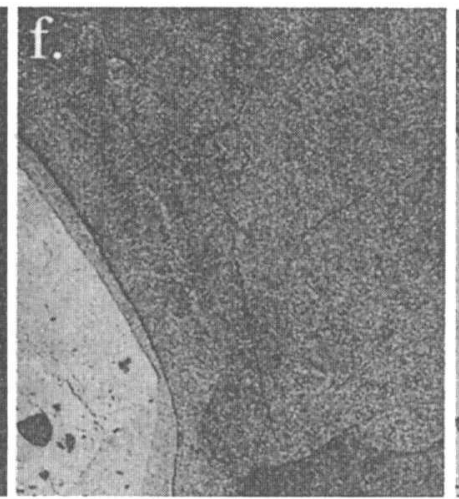

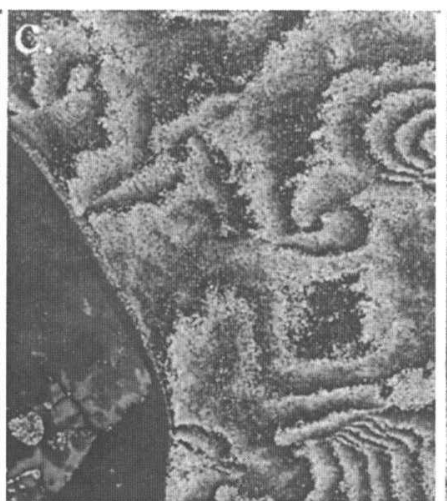

10 February to 13 February

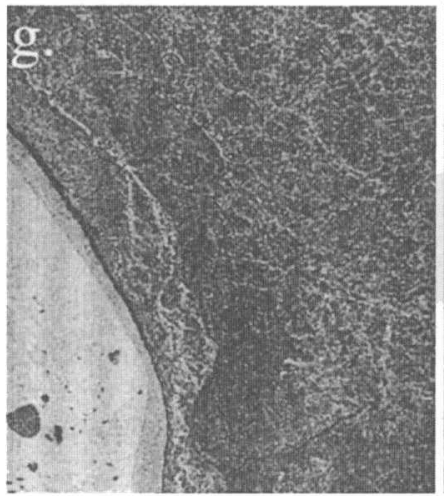

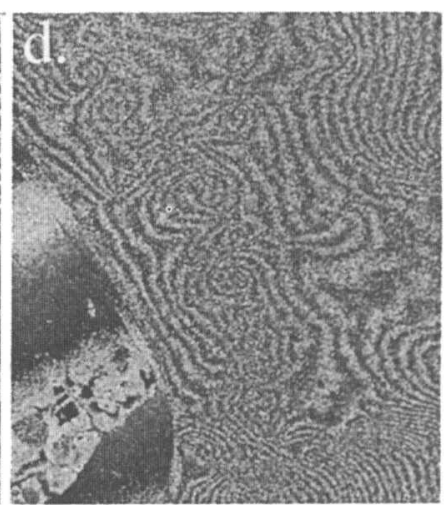

4 February to 13 February

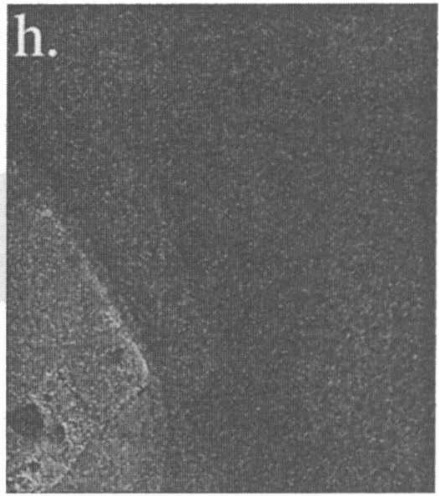

Fig. 8. Sub-scenes from each of the four interferogram (top row) and correlation (bottom row) mosaics covering the time period 15-24 March 1994. Each sub-scene is approximately $40 \mathrm{~km}$ by $50 \mathrm{~km}$. 
ing to the same forcing factors as the pack-ice zone but at a much smaller scale.

\subsection{Nine-day interval interferogram mosaics}

\subsubsection{December mosaic}

The 24 December 1993 to 2 January 1994 interferogram mosaic (Fig. 9, hercafter referred to as the December mosaic) is dominated by two large features. The first lies just south of the Medvezh islands (cnclosed area l in Fig. 9) and contains two "centers" from which the fringes fall away. This feature is cvident only in the 30 December 1993 to 2 January 1994 3 day interval interferogram, when there was discernible $>500 \mathrm{~m} /$ time interval) northward ice motion throughout the arca covered by the interferogram (Fig. 5). The Medvezh islands present at least a partial barrier to this ice movement, and this second feature represents, in part, a bulging of the sea ice in response to this impediment to uniform latcral motion.

The second large feature in the Deccmber mosaic (cnclosed area 2 in Fig. 9) lies across the bottom half of the mosaic. In general, this feature slopes "downhill" from northeast to southwest, and the fringes fall away from a central axis, creating a bulging, tongue-like feature. Its location and con- figuration closely mirror the Kolyma submarine valley (Fig. 1). The winds are predominantly offshore over the 9 day period, and it is thus likely that upwelling (Lafond, 1980) through the canyon is occurring. Hence, this feature appcars to be linked with localized oceanic forcing set up by the atmospheric conditions.

\subsubsection{February mosaic}

The 4-13 February 1994 interferogram mosaic (Fig. 10, hereafter referred to as the February mosaic) is very complex and noisy, making it difficult to interpret. The features of primary interest are the numerous "bull's-eyes" or apparent concentric fringe-type features of varying sizes. "Bull's-cyes" have been identified in interferograms of the Greenland ice sheet (Joughin and others, 1995; Rignot and others, 1995) and Landers and Eureka Valley, California, after earthquakes (Massonnet and others, 1994; Massonnet and Feigl, 1995; Peltzer and Rosen, 1995). In those cases, the quasi-circular features appeared to represent either concave or convex features, i.c. cither a bowl-shaped feature or a moundshaped feature, which were not necessarily symmetrical. The "bull's-eyes" in the February mosaic do not fit this model. They are composed of a half-bowl-shaped feature immediately adjacent to a half-mound-shaped feature, with

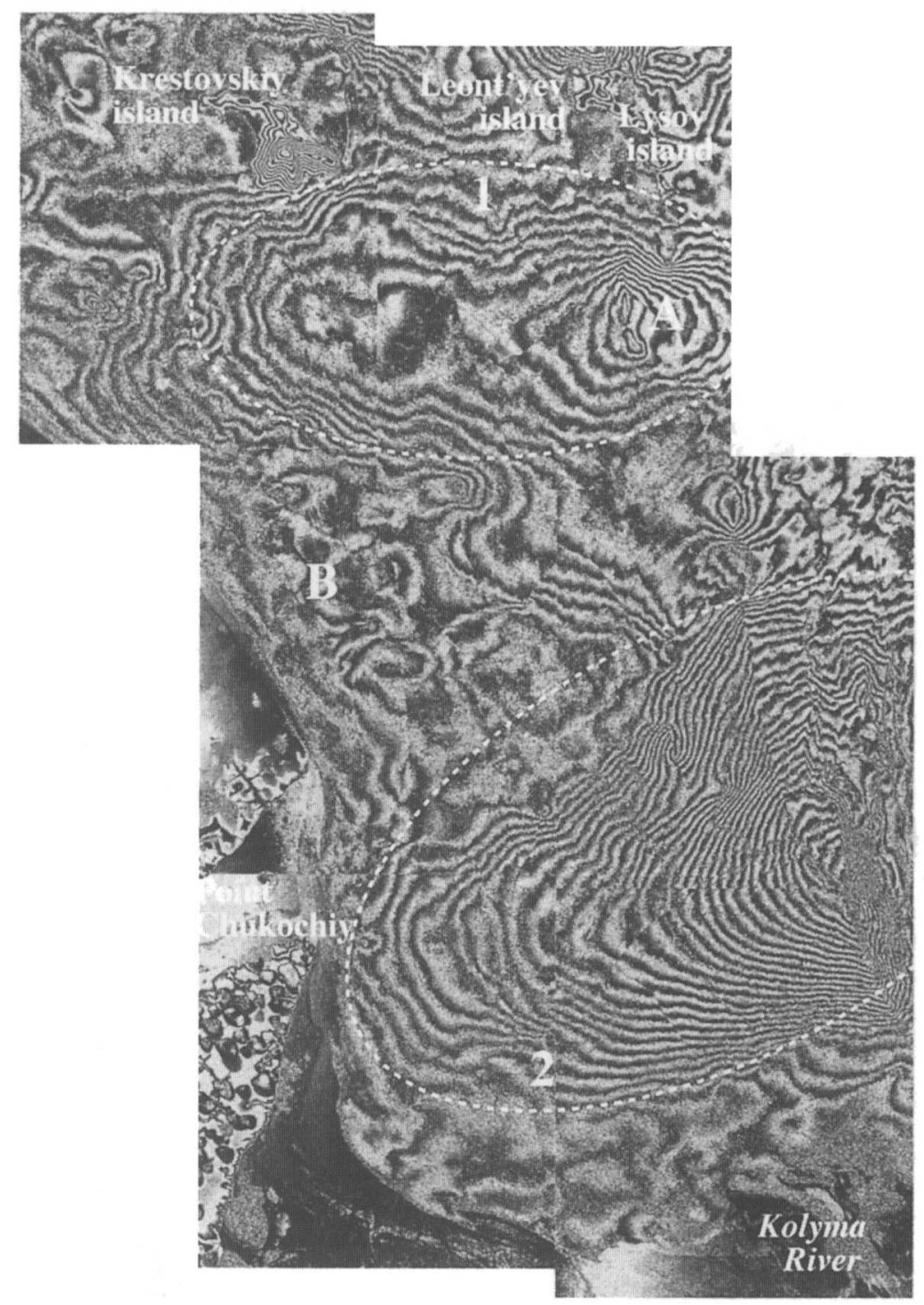

Fig. 9. Mosaic of the interferograms generated from data acquired on 24 December 1993 and 2 January 1994 (9 day interval). The two large features that dominate this mosaic are enclosed by dashed lines. They are: (1) a semi-enclosed feature that appears to have two "centers"; and (2) a large, tongue-shaped feature oriented along a northeast-southwest axis which lies over the Kolyma submarine valley. A and $B$ indicate features referred to in the text. 


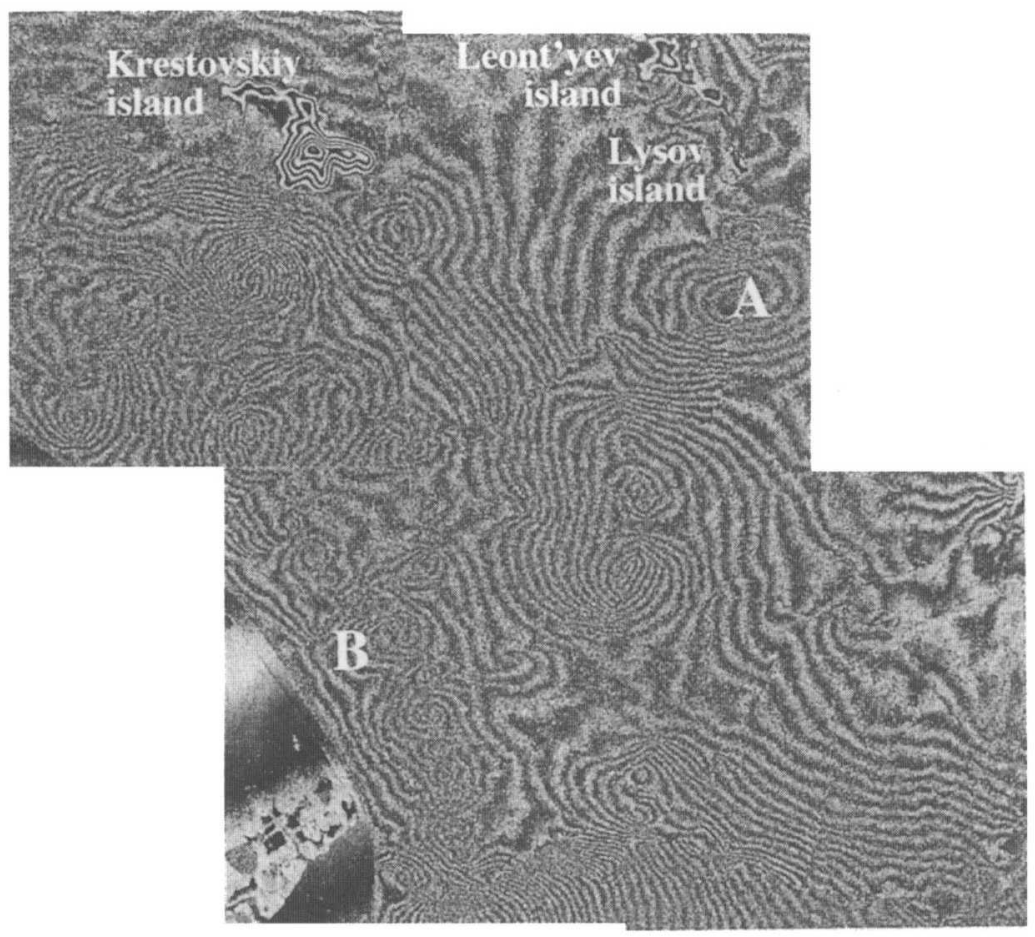

Fig. 10. Mosaic of the interferograms generated from data acquired on 4-13 February 1994 (9 day interval). This mosaic is dominaled by "bulls-eye" features. $A$ and $B$ indicate features referred to in the text.

discontinuities (fractures) running through their centers. This interpretation was tested by unwrapping an interferogram. The February mosaic was too noisy to be successfully unwrapped, so the 4-7 February interferograms were used as a surrogate becausc they contain most of the information found in the 9 day interval mosaic (Fig. 7). The 3 day interval interferogram was cleaned using a median filter to reduce the noisiness of the data. Then the filtered interferogram was unwrapped using least-squares and branch-cut-based algorithms (Ghiglia and Romero, 1994; Wang and Li, 1999). The unwrapped phase pattern resulting from the branch-cut method is presented in Figure 11. It clearly shows that a half-bowl-shaped feature and a halfmound-shaped feature are separated by a crack in the middlc. The least-squares method gives a similar result, with the central discontinuity blurred and a different relative elevation betwecn the two halves.

\subsubsection{March mosaic}

The 15-24 March 1994 interferogram mosaic (Fig. 12, hereafter referred to as the March mosaic) is dominated by abrupt discontinuities in the fringe patterns. Indeed, these interferograms appear to be broken into distinct "plates", each with well-defined edges, equidistant fringes and a unidirectional slope magnitude across any given unit. Since the phases in the interferogram are not unwrapped, it should not exhibit discontinuities unless spatially discontinuous motions (breaks) occur during the period spanned by the interferogram pair (Zcbker and others, 1994). These phase discontinuities represent $10-100 \mathrm{~mm}$ scale displacement discontinuities of the sea-ice cover due to motion. The cquidistant fringes imply a nearly rigid behaviour which indicates a near-uniform translation of the position of the ice and/or rotation/tilting of the icc "plates" (Peltzer and others, 1994). Li and others (1996a) saw similar features in 3 day interval interferograms generated for the fast-ice zonc near Prudhoe Bay, Alaska (spanning 18-30 January 1992). They speculated that most of the fringes reflected tilting and/or differential horizontal movements in the cross-track dircction, and attributed the discontinuities to differential motion across cracks, grounded shear or pressure ridges, unconsolidated ridges or narrow zones of smooth sheet ice grounded on shoals.

One recurring feature in all of the March correlation diagrams (Fig. 8) is a narrow zone of very low corrclation along the coast; this manifests itself as a zone of decorrelation in the interfcrograms (Figs 8 and 12). This feature is due to lateral motion of the sea ice away from the coast. Using Equation (1), a lateral motion of $18 \mathrm{~m}$ over the 9 day interval can be inferred from this mosaic.

\subsubsection{Correlation between fringe patterns and sea-ice features}

Linear deformation features (cracks and ridges) and largescale discontinuities in ice ages (Fig. 2) were mapped from the low-resolution SAR image acquired on 30 December 1993, and their locations compared with prominent features in the three 9 day interferogram sets. In the December mosaic (Fig. 9), the linear discontinuity along the eastern edge of the southern tongue-like feature coincides exactly with the discontinuity in ice ages (see Figs 2 and $3 a$ ). The centers of several circular features also lic directly over this discontinuity (c.g. item A, Fig. 9). A series of small circular fringes along the coastline (e.g. item B, Fig. 9) appear to fall on or adjacent to lincar deformation features, i.e. ridges. Similarly, in the February mosaic, circular features lie directly over the iceage discontinuity (e.g. item A, Fig. 10), and centers of "bull's-eyes" lie on linear deformation features, or entire "bull's-eyes" are found between two such features (c.g. itcm B, Fig. 10). For the March mosaic (Fig. 12), there is less correlation between the stationary, large-scale ice features visible on the low-resolution SAR images and the boundaries of the ice "plates". However, as can be seen in Figure 8, the linear zones of low correlation in the correlation diagram correspond exactly to the discontinuities in the phase diagram. These linear zones of low correlation represent fractures in the ice that are so narrow that they do not appear in the 

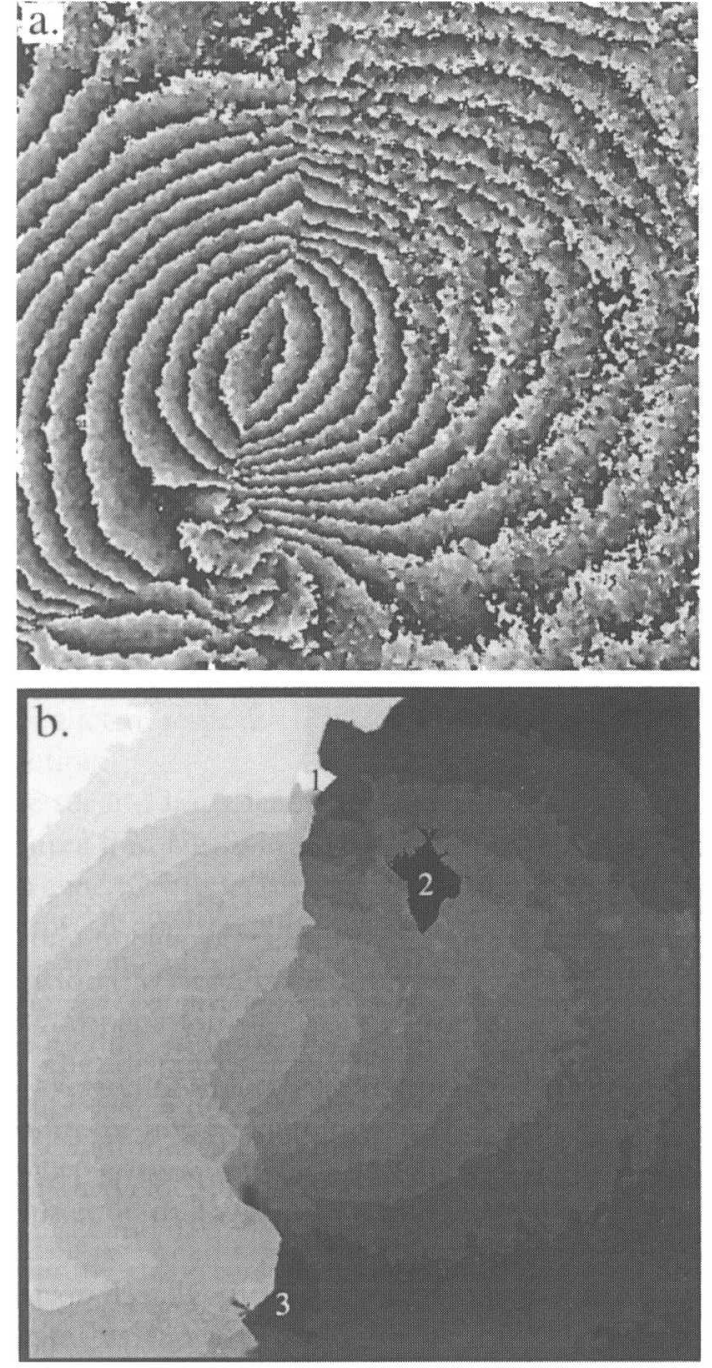

Fig. 11. A "bull's-eye" feature from the 4-7 February interferogram sel was (a) cleaned by median filter and (b) unrerapped using a branch-cut-based method. A discontinuity is clearly visible through the unwerapped feature. In (b), a half-borel-shaped feature (on the left) and a half-moundshaped feature (on the right), with a central crack (discontinuity) separating them, confirms that this is not a true, coherent "bull's-ye". The small white zone (I) is an area of local error, and the lwo black zones (2 and 3) are areas where the algorithm could not resolve phase zalues.

low-resolution images because of the difference in the pixel sizes and resolutions between the two image types.

When the dominant features from the December, February and March mosaics were mapped and compared, almost all of the "bull's-eyes" from the December and February mosaics fell on or very near to the ice-plate boundaries of the March mosaic (Fig. 13). Wecks and others (1972) examined ridge data from the Bering, Chukchi and Beaufort Seas and found that the lack of local isostatic adjustment common in these ridges causcd deflection of the ice in adjacent areas and was severe enough in some cases to induce cracking of the ice sheet adjacent to the ridge. The cracks adjacent to the ridges may develop through the winter and become the boundaries of the ice "plates" later in the year (c.g. March interferogram). This explains the close relation between the linear deformation features visible in the low-resolution SAR images and the cracks visible in the correlation diagrams later in the season. The "bull's-eyes" are clearly areas of high stress, where cracks develop later.

\subsubsection{Fringe orientation and density}

In interferograms of sea ice, the fringe orientation and fringe density are primarily the result of lateral motion, tilting and rotation of the ice. Tilting can produce fringes in any orientation. Rotation produces fringes perpendicular to the along-track direction. A component of lateral displacement in the cross-track direction produces fringes parallel to the along-track direction. Any combination of tilting, rotation and lateral displacement produces fringes off the perpendicular or parallel orientation.

Ice motion south of the Medvezh islands is usually $<500 \mathrm{~m} /$ time interval, although discernible ice displacement $(>500 \mathrm{~m} /$ time interval) was detected once in the ice-motion vector fields (Fig. 5). Thus, lateral displacement of the sea-ice cover is a factor continuously contributing to the fringe patterns. Under the tilting assumption, the slope angles for the slope-direction/magnitude measurements on the threc 9 day interval interferogram sets ranged between $0.00027^{\circ}$ and $0.00584^{\circ}$, which is well below the threshold of decorrclation (about $0.1^{\circ}$ ) citcd by Pcltzer and others (1994). These slope angles translate into slope changes of $4.7 \mathrm{~mm} / \mathrm{km}$ to $101.9 \mathrm{~mm} / \mathrm{km}$. The surface tilt of the sea ice mirrors the surface tilt of the underlying ocean. Over mesoscale distances, the sea-surface tilt is influenced by the Coriolis effect and differcntial atmospheric pressure: the sea surface behaves like an inverted barometer with a 1 mbar pressure difference corresponding to a nearly $10 \mathrm{~mm}$ sea-level difference (Pattullo, 1980). Based on the IABP daily surfacc-pressurc charts for this period (Rigor and Colony, 1995; Rigor and Heiberg, 1995), the atmospherically induced sea-surface tilt across the East Siberian Sea ranges from approximately 0.06 to $0.2 \mathrm{~mm} /$ $\mathrm{km}$ (over hundreds of $\mathrm{km}$ ), and is not in the samc dircction as the tilt indicated by the interferograms, for the periods interferograms were generated. One would expect to see reversals of the dircction of the fringes from time to time as the sca ice tilts in response to forcing factors and then falls back or reverses tilt direction as the forcing relaxes or changes direction. This phenomenon is not observed in any of the three 3 day interval interferogram series (Figs 6-8), although this may simply be because these time series are too short. Hence, it is likely that simple atmospherically induced sea-surface tilt makes only a small contribution to the surfacc slopes calculated from the interferograms. Small-scale rotation ( $<0.2^{\circ}$ decorrelation threshold: Peltzer and others, 1994) of ice blocks within the ice cover is possible, and this type of displacement produces the greatest increase in fringe density with the lcast amount of motion, making it a likely contributing factor for some of the high fringe densities (Fig. 12).

Where possible, the slope dircction and slope magnitude $(\mathrm{mm} / \mathrm{km})$ were determined from the interferograms. Only zones of parallel or near-parallel fringes were considered, and every effort was made to sample over the entirc mosaic. In general, the dominant slope direction is different for each mosaic, and the slope magnitude decreases with time as does its standard deviation. The December mosaic is not dominated by any particular slope direction, although $45 \%$ of the values $(n=47)$ fall into the westerly to northwesterly bins, which is the generally dominant wind direction for this 9 day period. Similarly, the change in slope values is not very well grouped (mean $=32.0 \pm 21.3 \mathrm{~mm} / \mathrm{km}$ ). This lack of an ovcrriding trend in the data is due to the bending of the ice in response to the oceanic forcing which causes a more complex spatial distribution of slope-magnitude values. This in turn leads to zones of poorly defined fringes 


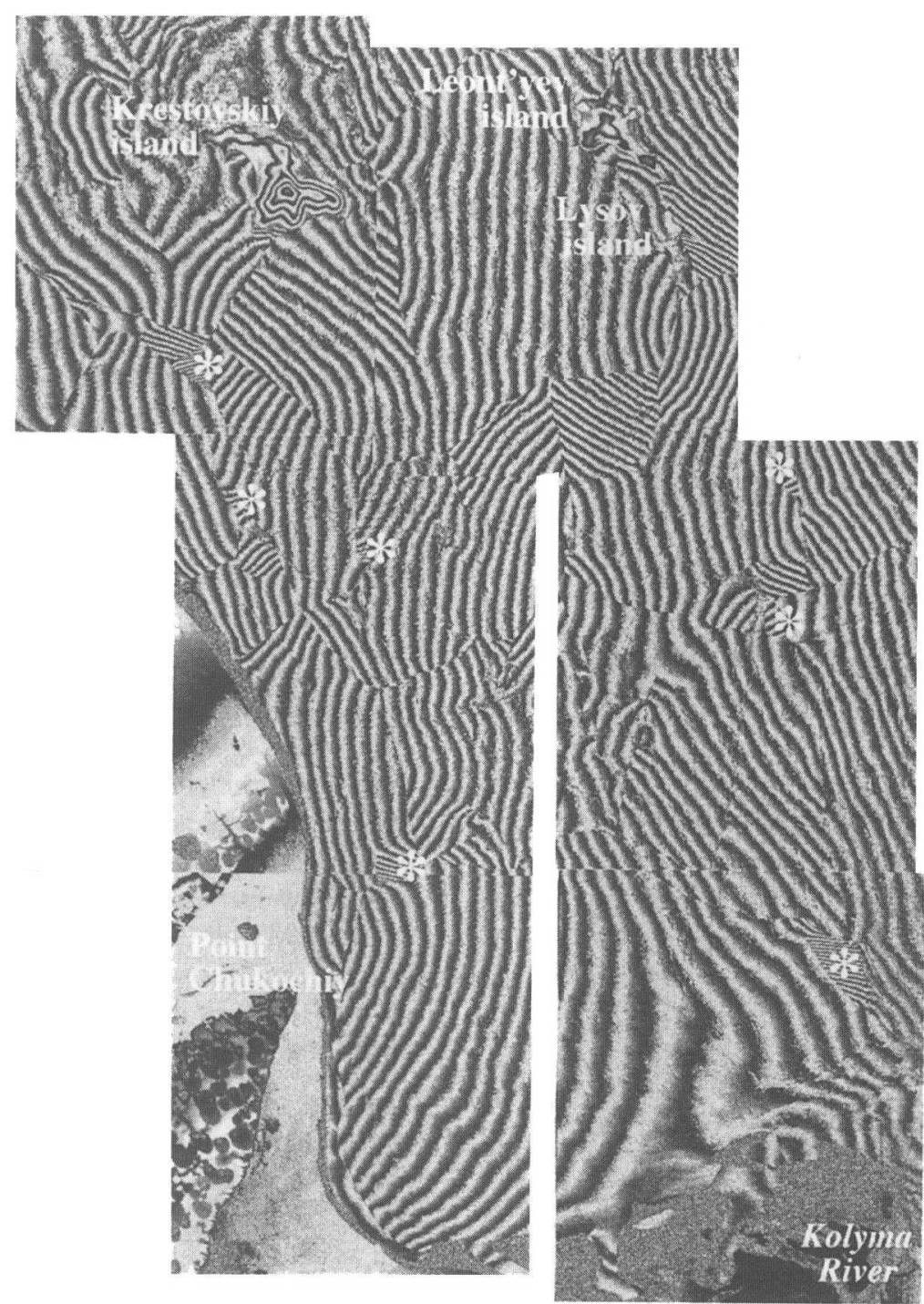

Fig. 12. Mosaic of the interferograms generated from data acquired on 15-24 March 1994 (9 day interval). This mosaic is dominated by ice "plates", which are defined by discontinuities in the phase changes. The zhite asterisks indicate "plates" that are dominated by either tilt or rotation. There is a vertical data gap through the center of the lower two-thirds of this mosaic.

(sec Fig. 9) which result in non-uniform sampling across the interferogram.

The February mosaic is dominated by a westerly slope, with $83 \%$ of values $(n=41)$ falling into the southwesterly to northwesterly bins, but the slope-magnitude values are quite variable $($ mean $=29.7 \pm 17.4 \mathrm{~mm} / \mathrm{km}$ ). The high uniformity of the slope direction, despite the complexity of the interferogram mosaic, is duc to the unidirectional nature of the "bull's-eyes". The March mosaic is dominated by an easterly slope, with $96 \%$ of values $(n=57)$ falling within the northcastcrly to southeasterly bins, with $42 \%$ in the easterly bin alone. The slope-magnitude values are also well clustered (mean $=19.2 \pm 11.4 \mathrm{~mm} / \mathrm{km})$, with $62 \%$ falling betwecn $12.5 \mathrm{~mm} / \mathrm{km}$ and $20.0 \mathrm{~mm} / \mathrm{km}$. This fairly uniform slope direction, coupled with the well-clustered change of slope values, indicates that, although the ice cover at this time is very fractured, these large ice blocks represent a semi-rigid icc shect that acts in a fairly coherent manner. The dominant slope directions for the February and March interferogram mosaics (westerly and casterly, respectivcly) roughly correspond to the dominant ice-motion directions in the pack ice for the same time periods (see Fig. 5). The December mosaic shows a similar but weaker correlation. Thus, the ice south of the Medvezh islands appears to be reacting to the same atmospheric/oceanic forcing as the pack ice, but with local variations in sea-ice response duc to the more complicated oceanic conditions in the nearshore regions.

'There are no datasets for tidal conditions in the nearshore region of the East Siberian Sea for the winter of 1993-94, so it is difficult to quantify what effects they have on the interferograms. Li (unpublished data) was unable to detect tidal effects in interferograms generated in the Prudhoe Bay area ( $\mathrm{Li}$ and others, 1996a) using concurrently measured tidc heights. Since the tidal ranges in these two regions are similar (Beaufort Sca, $<0.6 \mathrm{~m}$; East Sibcrian Sea, $<0.5 \mathrm{~m}$ ), it is likely that the tidal effects in the East Siberian Sea are also small. Negligible tidal effects are indicated by the fact that there are no fringes around the islands.

Overall, the December, February and March interferograms represent a time series of the sea-ice response to the atmospheric pressure-induced changes in the oceanic conditions south of the Medvezh islands. At the end of December, the sea ice is still relatively thin and it bends and undergoes lateral displacement because of the predominantly offshore winds and resultant upwelling. At the start of February, the ice cover is thicker and undergoes lateral displacement, but it has become extensively cracked, which introduces new boundaries across which there is differential forcing by the atmosphere and ocean. By the end of March, the network of fractures is very well established and the sea-ice cover now 


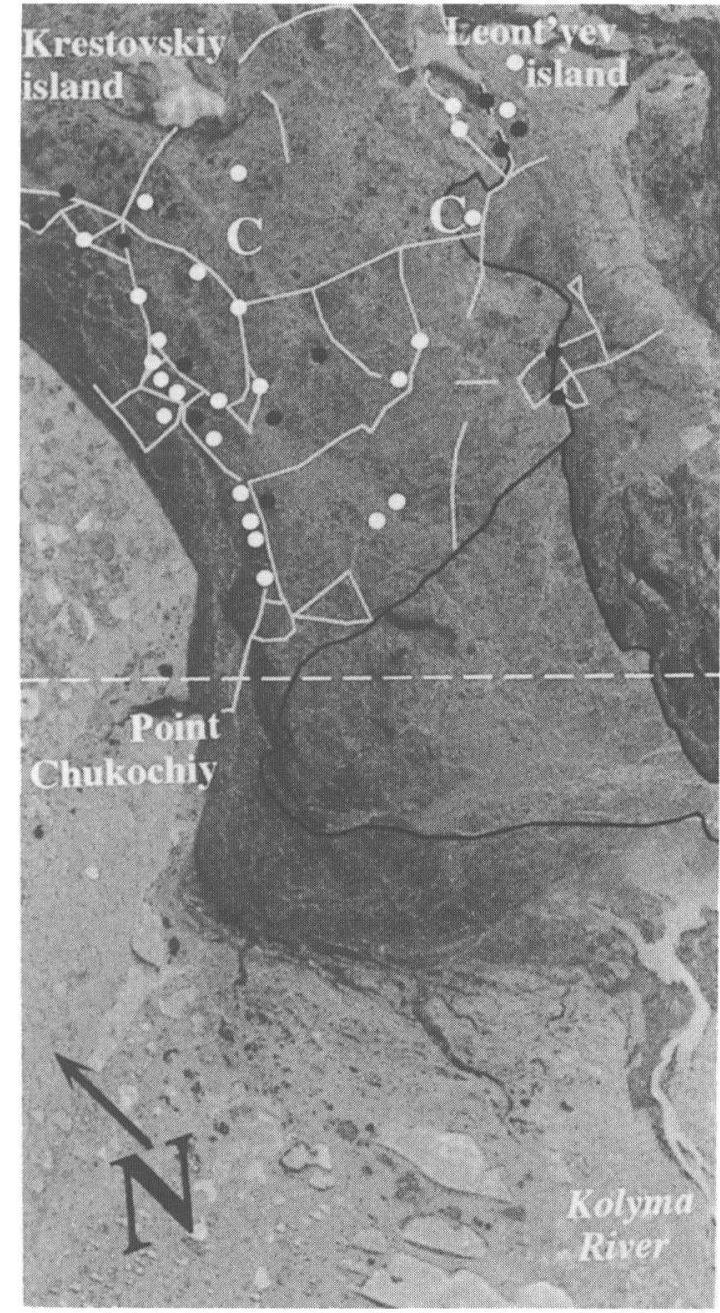

Fig. 13. The dominant fealures from the three 9 day interval interferograms were mapped onto the 30 December 1993 lowresolution ERS-1 SAR mosaic (see Fig. 2). The solid black circles are the centers of quasi-circular features from the December interferogram (Fig. 9). The Cis denote the location of the "centers" in the large feature directly south of the islands. The dark, solid line delimits the large feature over the Kolyma submarine valley (see Fig. 9) and the boundary between different ages and ice thicknesses (see Fig. 2). The solid white circles are the centers of self-contained features from the February interferogram ( Fig. 10). The dolled white line represents the southern limit of the February mosaic. The solid gray lines are the discontinuities (ice-plate boundaries) in the March interferogram (Fig. 11).

comprises discrete plates which act in a fairly coherent manner: fringes are primarily due to lateral motion, with local variations due to tilt/rotation.

\section{SUMMARY AND CONCLUSIONS}

Although this study is limited in its spatial and temporal coverage, the following summary and conclusions can be made concerning the combincd use of SAR-derived icemotion vectors (displacement) and the technique of SAR interferometry with regard to sea ice in the East Siberian Sea:

The ice-motion vector fields can be used to identify three zones: the stationary-, transitional- and pack-ice zones. 'These vary spatially through time and disappear completely on several occasions.
While true landfast ice conditions probably only exist south of the Medvezh islands in this region, stationary $(<500 \mathrm{~m} /$ time interval) ice conditions can exist for short periods ( 3 day interval) as far north as $74.5^{\circ} \mathrm{N}$.

Rapid (3 day interval) changes in the dircetion and extent of pack-ice motion can be seen in the ice-motion vector-ficld time series. Longer-term ( $\geq 1$ month) trends in the dominant direction of motion also emerged from these data and are related to the average monthly surface air-pressure patterns.

Interfcrograms can be successfully generated over the landfast ice in the nearshore area. This icc is subject to atmospheric and oceanic forcing which can vary greatly on a short (daily) time-scale, making the interferograms difficult to interpret without supplementary cnvironmental datasets which are currently unavailable.

The complexity and degree of corrclation of the 3 day interval interferograms is related to the extent of the stationary-ice zone which is a function of the intensity and duration of the atmospheric forcing factors. The stationary-ice zone responds to the samc forcing factors as the pack-ice zone. This is corroborated by the general agrecment between the dominant slope direction of the February and March 9 day interval intcrferograms and the general wind patterns, which indicate that the nearshore ice and thc pack icc react to the same atmospheric forcing but on different scales.

The three 9 day interval interferogram mosaics reveal the changing nature of the sea ice in response to the atmosphcric/occanic forcing. The sea ice undergoes very small-scale lateral displacement during the cntire winter, but as the ice cover evolves it responds differently to forcing factors. In Deccmber, the relatively thin ice is dominated by oceanic forces produced by predominantly offshore winds which effect $10-100 \mathrm{~mm}$ scale changes in the sea-ice elevation. The February mosaic is dominated by "bull's-eye" features which are related to the locations of linear deformation features in the sea ice, which constitute new boundaries in the forcing field. By March, the ice cover is thicker, with cxtensive cracks throughout, and the mosaic is dominated by phase discontinuitics producing ice "plates" which respond in a fairly coherent manner to atmospheric/oceanic forcing.

Many of the key features in the 9 day interval interferograms are linked to deformation features in the sea-ice cover such as ridges, cracks and major discontinuitics in the ice thickness.

The correlation diagrams are very useful for sea-icc applications. They can be used to document the relative stability of the sea-ice cover over the time interval of the interferogram. Narrow fractures which are completely obscurcd in the amplitude diagrams can be seen clearly in correlation diagrams with highly corrclated backgrounds. This makes it possible to accurately map these features.

Lse of SAR-derived ice-motion vectors and SAR interferometry shows considerable promisc in the study of sca-ice-ocean-atmosphere interactions in nearshore, continental-shclf arcas where sea ice plays a significant role in sediment transport, heat transfer and cold, dense water formation. This combination of techniques could 
also be of value in offshore engineering, i.e. the search for oil and gas, navigation and the operation of icebreakers and cargo vessels.

\section{ACKNOWLEDGEMENTS}

This research was supported by the U.S. Office of Naval Research through the Arctic Nuclear Wastc Asscssment Program (grant N000014-94-1-0973). The authors are grateful to E. Meitner (Geophysical Institute Summer Intern 1995) for modifying the ASF-GPS code and to R. Guritz (ASF Science Team Leader) and K. Partington (ASF RGPS Scientist 1996-97) for subsequent software support. We would also like to thank L. Shapiro and W. Weeks for useful discussions on sea ice, and the two anonymous reviewers for their comments. All ERS-1 images used in this study were acquired and processed at the ASF. All ERS-1 SAR images are copyrighted by ESA.

\section{REFERENCES}

Barnes, P.W., D. M. Schell and E. Reimnitz, eds. 1984. The Alaskan Beaufort Sea: ecosystems and environments. Orlando, FL, ctc., Academic Press.

Barnett, D. 1991 Sea ice distribution in the Soviet Arctic. In Brigham, L.W., ed. The Sortet maritime Arctic. Annapolis, MD, Naval Institute Press, 47-62.

Cavalieri, D. J. and S. Martin. 1994. The contribution of Alaskan, Siberian, and Canadian coastal polynyas to the cold halocline layer of the Arctic Ocean. 7. Geophys. Res., 99(C9), 18,343-18,362.

Drent, J. 1993. Commercial shipping on the Nurthern Sea Route. The Northern Mariner, $3(2), 1-17$.

Gabricl, A. K., R. M. Goldstcin and H. A. Zebker. 1989. Mapping small elevation changes over large areas: differential radar interferometry. $\mathcal{J}$. Geophys. Res., 94 (B7), 9183-9191.

Ghiglia, I). C. and I. A. Romero. 1994. Robust two-dimensional weighted and unweighted phase unwrapping that uses fast transforms and iterative methods. f. Opt. Soc. Am., Ser. A, 11, 107117.

Gineris, D. J. and F. M. Fetterer. 1994. An examination of the radar backscatter of sea ice in the East Siberian and Chukchi Seas. In Strin, T. I., ed. IGARSS'94., Surface and Atmospherir Remote Sensing. Technologies, Dala Analysis and Interpretation, Pasadena, Califormia, LSA. August 8-12, 1994. Proceedings. Vol. 1. Pisacataway, NJ, Institute of Electrical and Electronics Fnginecrs, 499-502.

Goldstein, R. M., H. Engelhardı. B. Kamb and R. M. Frolich. 1993. Satellite radar interferometry for monitoring ice sheet motion: application to an Antarctic icc strcam. Science, 262 (5139), 1525-1530.

Johnson, L., A. Grantz and J. R. Weber. 1990 . Bathymetry and physiography. In Grantz, A., L. Johnson and J.F. Sweeney, eds. The Arctic Ocean region. Boulder, CO, Geological Society of America, 6.3-78. (The Gcology of North America L.)

Joughin, I. R., D. P. Winebrenner and M. A. Fahnestock. 1995. Observations of ice-sheet motion in Greenland using satellite radar interferometry. Geophys. Res. Lett., 22 5), 571-574.

Kassens, H., H.W. Hubberten, S. M. Pryamikov and R. Stein, eds. 1994. Workshop un Russian-German cooperation in the Siberian shell seas: geo-system Laptev Sea. Ber. Polarforsch. 144.

Kwok, R. and G. Cunningham. 1993. Alaska SAR facility geophysical processor system data user's handbook (ive molion product, ice type produch, wave spectra product). Pasadena, CA, Jet Propulsion Laboratory. (JPL D-9526.)

Kwok, R., J. C. Curlander, R. McConnell and S. S. Pang. 1990. An icemotion tracking system at the Alaska SAR facility. IEEE $\mathcal{J}$. Oceanic Eng., OE-15 $11,44 \cdots 54$.

Lafond, E. C. 1980 . Upwelling. In Parker, S. P., ed. McGraze-Hill encyclopaedia of ocean and atmospheric sciences. New York, McGraw-Hill Book Company, $523-525$.

Li, F. K. and R. M. Goldstein. 1990. Studies of multi-baseline spaceborne interferometric synthetic aperture radars. IEEE Trans. Geosci. Remote Sensing, GE-28 (1), 88-97

Li, S., Z. Cheng and W. F. Weeks. 1995. A grid-based algorithm for the extraction of intermediate-scale sea-ice deformation descriptors from SAR icc motion products. Int. F. Remote Sensing, 16 (17), 3267-3286.

Li, S., L. Shapiro, I. McNutt and A. Jcffers. 1996a. Applications of satellite radar interferometry to the detection of sea ice deformation. \%. Remote Sensing Soc. $7 p n, \mathbf{1 6}(2,67-77$.

Li, S., M. Sturm and C. Benson. 1996b. Pattern of redistribution of winddrifted snow at Imnavait Creek on the North Slope, Alaska, during a storm in February, 1994, revealed by ERS-I SAR interferometry. In PIERS96 on Remote Sensing, 7uly 8-12, 1996, Innsbruck, Austria. Innsbruck, University of Innsbruck. Institut für Meteorologie und Geophysik, 50.

Madsen, S. N., H. A. Zebker and J. Martin. 1993. Topographic mapping using radar interferometry: processing techniques. IEEE Trans. Geosci. Remote Sensing, GE-31(1), 246-256.

Massonnel, D. and K. L. Feigl. 1995. Discrimination of geophysical phenomena in satellite radar interferograms. Geophys. Res. Lett., 22(12), 1537-1540.

Massonnet, D. and 6 others. 1993. The displacement field of the Landers earthquake mapped by radar interferometry. Nature, 364 6433, 138-- 142

Massonnet, D., K. Fcigl, M. Rossi and F. Adragna. 1994. Radar interferometric mapping of deformation in the year after the Landers earthquake. Naiure, $\mathbf{3 6 9}(6477), 227-230$.

Overland, J. E., S. L. McNutt, S. Salo, J. Groves and S. Li. 1998. Arctic sea ice as a granular plastic. 7. Geophys. Res., 103 (C10), 21,845-21,867.

Pattullo, J. G. 1980. Sca-level fluctuations. In Parker, S. P., ed. McGraze-Hilt encyclopaedia of ocean and atmospheric sciences. New York, McGraw-Hill Book Company, 402-405.

Peltzer, G. and P. Rosen. 1995. Surface displacement of the 17 May 1993 Eureka Valley, California, earthquake observed by SAR interferometry. Science, 268 25215$), 13331336$.

Peltzer, G., K.W. Hudnut and K. L. Feigl. 1994. Analysis of coseismic surface displacement gradients using radar interferometry: new insights into the Landers earthquake. f. Geophys. Res., 99(B11), 21,971-21,981.

Pfirman, S. L., H. Eicken, D. Bauch and W. F. Weeks. 1995. The potential transport of pollutants by Arctic sea ice. Sci. Total Environ., 159(2-3), $129 \cdot 146$.

Reimnitz, E. and D. Dethleff. 1994. Contrasts in Arctic shelf sea-ice regimes and some implications: Bcaufort Sca versus Laptev Sca. Mar. Geol. $119(3 / 4), 215-225$.

Rignot, E., K. C. Jezek and H. G. Sohn. 1995. Ice flow dynamics of the Greenland ice sheet from SAR interferometry. Geophys. Res. Lell, 22(5), 575-578.

Rignot, E. J., S. P. Gogineni, W. B. Krabill and S. Ekholm. 1997. North and nurth-east Greenland ice discharge from satellite radar interferometry. Science, 276 65.314$\}$, 934-937.

Rigor, I. and R. L. Colony. 1995. International Arctic Buoy Pregram dala report: January 1993 - 31 December 1993. Seattle, WA, University of Washington. Applied Physics Laboratory. (Technical Memorandum API -UW INM 4-9.5.

Rigor, I. and A. Heiberg. 1995. International Artic Buoy Program data report: 1 January 1994 - 31 December 1994. Scattle, WA, University of Washington. $\Lambda \mathrm{p}$ plied Physics Laboratory. (Technical Memorandurn APL-UW TM 6-95.)

Riska, K. and O. Salmela. 1994. Description of ice conditions along the Vorth-East Passage. Espoo, Helsinki University of 'lechnology. Arctic Offshore Rescarch Centre. (Memorandum M-192.)

Romanov, I.P. 1991. Ledyanoy pokroz arkticheskogo bassepna Ite cover of the Arctic basin. Leningrad, Arctic and $A$ ntarctic Institute.

Stern, H. L., D. A. Rothrock and R. Kwok. 1995. Open water production in Arctic sea ice: satellite measurements and model parameterization. $j$ Geophys. Res, 100 (C10), 20,601-20,612.

Thorndike, A. S. and R. Colony. 1982. Sea ice motion in response to geostrophic winds. $\bar{J}$. Geophys. Res, 87 (C8), 5845-5852

Timokhov, L. A. 1994. Regional characteristics of the Laptev and the East Siberian Seas: climate, topography, ice phases, thermohaline regime, circulation. Ber. Polarforsch. 144, 15-31

Wang, Z and S. Li. 1999. Phase unwrapping through a branch-cut based cut bridging and window-patching method. Applied Optics, 38 (5), 805-814

Weeks, W. F. 1994. Possible roles of sea ice in the transport of hazardous material. Arct. Res. U.S., 8, 34-52

Weeks, W. F., A. Kovacs and W. D. Hibler. 1972. Pressure ridge characteristirs in the Arctic coastal environment. In Wetteland, S. S. and P. Bruun, eds. Proceedings, 1st International Conference un Porl and Ocean Engineering under Artic Conditions, 23-30 August 1971, Trondheim, Norway. Vol. 1. Trondheim, Technical University of Norway, 152183

Weeks, W. F., P.W. Barnes, D. M. Rearic and E. Reimnitz. 1983. Statistica aspects of ice gouging on the Alaskan Shelf of the Bcaufort Sea. CRREL Rep. 83-21.

Zebker, H. A, and J.Villascnor. 1992. Decorrelation in interferometric radar echoes. IEEE Trans. Geosci. Remote Sensing, GE-30(5), 950959.

Zcbker, H. A., P. A. Rosen, R. M. Goldstein, A. Gabriel and C. L. Werner 1994. On the derivation of coseismic displacement lields using differential radar interferometry: the Landers carthquake. 7. Geophys. Res. $99(\mathrm{Bl0}), 19,617--19,634$. 